\title{
Instrument development, data collection, and characteristics of practices, staff, and measures in the Improving Quality of Care in Diabetes (iQuaD) Study
}

Martin P Eccles ${ }^{1 *}$, Susan Hrisos ${ }^{1}$, Jill J Francis ${ }^{2}$, Elaine Stamp ${ }^{1}$, Marie Johnston ${ }^{3}$, Gillian Hawthorne ${ }^{4}$, Nick Steen ${ }^{1}$, Jeremy M Grimshaw ${ }^{5}$, Marko Elovainio ${ }^{6}$, Justin Presseau ${ }^{1}$ and Margaret Hunter ${ }^{1}$

\begin{abstract}
Background: Type 2 diabetes is an increasingly prevalent chronic illness and an important cause of avoidable mortality. Patients are managed by the integrated activities of clinical and non-clinical members of primary care teams. This study aimed to: investigate theoretically-based organisational, team, and individual factors determining the multiple behaviours needed to manage diabetes; and identify multilevel determinants of different diabetes management behaviours and potential interventions to improve them. This paper describes the instrument development, study recruitment, characteristics of the study participating practices and their constituent healthcare professionals and administrative staff and reports descriptive analyses of the data collected.
\end{abstract}

Methods: The study was a predictive study over a 12-month period. Practices $(N=99)$ were recruited from within the UK Medical Research Council General Practice Research Framework. We identified six behaviours chosen to cover a range of clinical activities (prescribing, non-prescribing), reflect decisions that were not necessarily straightforward (controlling blood pressure that was above target despite other drug treatment), and reflect recommended best practice as described by national guidelines. Practice attributes and a wide range of individually reported measures were assessed at baseline; measures of clinical outcome were collected over the ensuing 12 months, and a number of proxy measures of behaviour were collected at baseline and at 12 months. Data were collected by telephone interview, postal questionnaire (organisational and clinical) to practice staff, postal questionnaire to patients, and by computer data extraction query.

Results: All 99 practices completed a telephone interview and responded to baseline questionnaires. The organisational questionnaire was completed by 931/1236 (75.3\%) administrative staff, 423/529 (80.0\%) primary care doctors, and 255/314 (81.2\%) nurses. Clinical questionnaires were completed by 326/361 (90.3\%) primary care doctors and 163/186 (87.6\%) nurses. At a practice level, we achieved response rates of 100\% from clinicians in 40 practices and $>80 \%$ from clinicians in 67 practices. All measures had satisfactory internal consistency (alpha coefficient range from 0.61 to 0.97; Pearson correlation coefficient (two item measures) 0.32 to 0.81); scores were generally consistent with good practice. Measures of behaviour showed relatively high rates of performance of the six behaviours, but with considerable variability within and across the behaviours and measures.

Discussion: We have assembled an unparalleled data set from clinicians reporting on their cognitions in relation to the performance of six clinical behaviours involved in the management of people with one chronic disease (diabetes mellitus), using a range of organisational and individual level measures as well as information on the

\footnotetext{
* Correspondence: martin.eccles@ncl.ac.uk

'Institute of Health and Society, Newcastle University, Baddiley-Clark Building,

Richardson Road, Newcastle upon Tyne, NE2 4AX, UK

Full list of author information is available at the end of the article
} 


\section{Background}

There is an enduring interest in healthcare in how best to predictably improve the quality of care received by patients. Different researchers approach this issue in different ways using different methods informed by a range of disciplinary backgrounds. Implementation science is the (usually multi-disciplinary) study of those factors that promote the uptake of the findings of clinical research into routine healthcare, thereby improving care for patients; it includes the study of both individual and organisational factors.

Within implementation science there has been increasing interest in the role of theoretical models to understand behaviours and identify techniques to change them. A systematic review of guideline implementation studies concluded that, by 1998, only 14 of 235 studies reported being inspired by or applying theories [1]. Since then there has been a steady increase in the number and type of studies testing or applying specific theories. Systematic reviews have quantified the empirical support for or predictive validity of social cognitive theories in predicting behaviour [2], diagnostic studies have explored a range of social cognitive, action and planning theories' prediction of intentions [3] and behaviour [4-6] and, using the theory of Planned Behaviour, have underpinned both intervention development [7] and process evaluation within randomised controlled trials $[8,9]$. Given the multiplicity of theories, authors have begun to offer various sorts of consolidated models that draw on multiple theories $[10,11]$.

However, the reality of the efforts to explore these issues has been slower than anticipated due to factors such as the challenges of operationalising theories, the need to characterise clinical care in terms of its constituent behaviours, the challenges of measuring behaviour, and the tension between focussing on individuals per se or as constituent members of teams and organisations.

Our previous work focussed on 'relatively simple' clinical behaviours performed by individual healthcare professionals [4-6,12-16], but the majority of healthcare delivered, at least in primary care in high income countries, is for more complex behaviours involved in the management of chronic diseases.

Globally, type 2 diabetes is an increasingly prevalent chronic illness and is an important cause of avoidable mortality. Despite guidelines defining standards of care (e.g., http://guidance.nice.org.uk/CG/Published), there is evidence of less than optimum care in a number of areas [17]. Whilst some of the variability in care will reflect variation in patient physiology and behaviour, it will also reflect differences in the clinical management behaviours of individual clinicians and the organisations they work in. In the United Kingdom, patients are managed by the integrated activities of clinical and non-clinical members of primary care teams and therefore, whilst clinicians still perform individual clinical behaviours, process measures of care and patient outcomes reflect a complex mix of individual clinicians' behaviours (e.g., examining a patient's feet), sequential behaviours across clinicians (e.g., managing a patient's blood pressure, BP), and sequential behaviours across administrative and clinical staff (e.g., taking a blood sample to assess glycaemic control and then adjusting medication if appropriate).

The 'Improving The Delivery Of Care For Patients With Diabetes Through Understanding Optimised Team Work And Organisation In Primary Care' study-subsequently shortened to 'Improving Quality of Care in Diabetes (iQuaD)' Study (see study protocol for further detail [18])-aimed to investigate these issues. Designed as a predictive study (over 12 months), it aims to investigate organisational, team, and individual factors determining the multiple behaviours needed to manage diabetes and identified multilevel determinants of different diabetes management behaviours and potential interventions to improve them. This paper describes the instrument development, study recruitment, characteristics of the study participating practices and their constituent healthcare professionals and administrative staff, and reports the descriptive analyses of the data collected.

\section{Methods}

\section{Study design and overview}

The study was a predictive study over a 12-month period. In summary, practice attributes and a wide range of individually reported measures were measured at baseline; measures of clinical outcome were collected over the ensuing 12 months, and a number of proxy measures of behaviour were collected at 12 months (detailed in Table 1).

At baseline we collected:

1. Structural and functional characteristics of the participating primary care practices;

2. Individuals' theory-based, self-reported cognitions about team functioning and practice organisational behaviour in their primary care practice (all staff); 
Table 1 Summary of variables, data collection methods and instruments, types and timings of data collected

\begin{tabular}{|c|c|c|c|c|}
\hline Variables & Instrument & Data collected & $\begin{array}{l}\text { Level and } \\
\text { data source }\end{array}$ & $\begin{array}{l}\text { Time } \\
\text { period }\end{array}$ \\
\hline $\begin{array}{l}\text { Structural and functional } \\
\text { characteristics of practices }\end{array}$ & $\begin{array}{l}\text { Structured } \\
\text { telephone } \\
\text { interview }\end{array}$ & $\begin{array}{l}\text { Practice demographics (e.g., staffing levels; skill mix) and } \\
\text { functional characteristics (e.g., frequency and type of } \\
\text { meetings held, staffing levels, staff responsibilities (both } \\
\text { in general and in relation to diabetes); access to } \\
\text { external services within primary and secondary care }\end{array}$ & $\begin{array}{l}\text { Practice } \\
\text { Practice manager, } \\
\text { lead GP or nurse } \\
\text { for diabetes }\end{array}$ & $\begin{array}{l}\text { March to } \\
\text { August } 2008\end{array}$ \\
\hline $\begin{array}{l}\text { Individuals' self-reported cognitions } \\
\text { about their organisation }\end{array}$ & $\begin{array}{l}\text { Baseline } \\
\text { organisational } \\
\text { postal } \\
\text { questionnaire }\end{array}$ & $\begin{array}{l}\text { Respondent demographics. Perceptions of: } \\
\text { organisational justice, team climate, organisational } \\
\text { citizenship and job control and demand, in general and } \\
\text { (TCl, JCD) in relation to the provision of diabetes care, } \\
\text { work stress, Plans to change employment, sickness } \\
\text { absence, identification of key staff involved in provision } \\
\text { of diabetes care. }\end{array}$ & $\begin{array}{l}\text { Individual } \\
\text { All practice staff }\end{array}$ & $\begin{array}{l}\text { September } \\
\text { to } \\
\text { December } \\
2008\end{array}$ \\
\hline $\begin{array}{l}\text { Individuals' self-reported cognitions } \\
\text { about six diabetes behaviours }\end{array}$ & $\begin{array}{l}\text { Baseline clinical } \\
\text { postal } \\
\text { questionnaire }\end{array}$ & $\begin{array}{l}\text { Theory based perceptions and beliefs in relation to } \\
\text { performing the six target behaviours. }\end{array}$ & $\begin{array}{l}\text { Individual } \\
\text { Clinicians* }\end{array}$ & $\begin{array}{l}\text { September } \\
\text { to } \\
\text { December } \\
2008\end{array}$ \\
\hline \multicolumn{5}{|l|}{ Behaviour data } \\
\hline Simulated behaviour & $\begin{array}{l}\text { Baseline clinical } \\
\text { postal } \\
\text { questionnaire }\end{array}$ & Scores on four clinical scenarios & $\begin{array}{l}\text { Individual } \\
\text { Clinicians* }\end{array}$ & $\begin{array}{l}\text { September } \\
\text { to } \\
\text { December } \\
2008\end{array}$ \\
\hline Self-reported behaviour & $\begin{array}{l}\text { 12-month } \\
\text { clinician postal } \\
\text { questionnaire }\end{array}$ & $\begin{array}{l}\text { Performance of the six target behaviours of interest } \\
\text { over the } 12 \text { months since the baseline survey }\end{array}$ & $\begin{array}{l}\text { Individual } \\
\text { Clinicians* }\end{array}$ & $\begin{array}{l}\text { September } \\
\text { to } \\
\text { December } \\
2009\end{array}$ \\
\hline $\begin{array}{l}\text { Patient physiological, biochemical, } \\
\text { and drug data, and clinician diabetes } \\
\text { management behaviours }\end{array}$ & $\begin{array}{l}\text { Structured query } \\
\text { of practice } \\
\text { computer data }\end{array}$ & $\begin{array}{l}\text { Patient physiological, biochemical and drug data and } \\
\text { clinician diabetes management behaviours relating to } \\
\text { the performance of the six target behaviours over the } \\
\text { previous } 12 \text { months. }\end{array}$ & $\begin{array}{l}\text { Practice } \\
\text { Patients** }\end{array}$ & $\begin{array}{l}\text { Conducted } \\
\text { September } \\
\text { to } \\
\text { December } \\
2009 \\
\text { Covers } \\
\text { August } 2007 \\
\text { to } \\
\text { September } \\
2009\end{array}$ \\
\hline Patient report of clinician behaviour & $\begin{array}{l}12 \text { month } \\
\text { patient postal } \\
\text { questionnaire } \\
\text { survey }\end{array}$ & $\begin{array}{l}\text { Performance of four of the six target behaviours over } \\
\text { the previous } 12 \text { months. }\end{array}$ & $\begin{array}{l}\text { Practice } \\
\text { Patients*** }\end{array}$ & $\begin{array}{l}\text { September } \\
\text { to } \\
\text { December } \\
2009\end{array}$ \\
\hline QOF data & $\begin{array}{l}\text { National } \\
\text { database }\end{array}$ & $\begin{array}{l}\text { Performance indicators for diabetes and primary care } \\
\text { practice organisation }\end{array}$ & Patients** & $\begin{array}{l}\text { May } 2008 \text { to } \\
\text { April } 2009\end{array}$ \\
\hline
\end{tabular}

* Involved in care of patients with diabetes

** All patients in practice with type 2 diabetes

*** Random sample of patients with type 2 diabetes

3. Individuals theory-based, self-reported cognitions about performing the six clinical behaviours (clinicians only);

4. Simulated behaviour data using four clinical scenarios (clinicians only).

At 12 months we collected:

1. Self-reported performance of the six clinical behaviours (clinicians only)

2. Physiological, biochemical, and drug data and clinician diabetes management behaviours from practice computer systems on all patients with diabetes managed within the participating primary care practices

3. Patient report of clinician behaviour from a sample of patients with diabetes managed within the participating primary care practices

4. Quality and Outcome Framework data for the participating primary care practices

\section{Setting, recruitment, and participants}

Practices were recruited from within the UK Medical Research Council General Practice Research Framework (MRC GPRF). When conducting similar previous studies 
with individually recruited primary care doctors [5], we had experienced low response rates in the face of long questionnaires. In order to be able to describe, characterise, and explore whole primary care practices, we wanted to achieve as close as possible to a $100 \%$ team response rate for the survey instruments from each practice. MRC GPRF practices volunteer to be research active and can directly receive funding to support their participation in research studies; practices were offered full reimbursement for the staff time taken to complete all study activities (including questionnaire completion) on condition that practice completion rates were satisfactory.

Recruitment was by postal invitation via the GPRF administration, with telephone follow-up of interested practices by the study research associate. Participants were all the clinical and non-clinical members of the primary care team in the practices recruited to the study.

\section{Clinical behaviours}

To investigate the care offered to patients we identified six clinical behaviours (Table 2) performed in the management of patients with diabetes. These were chosen to: cover a range of clinical activities (prescribing, nonprescribing); reflect decisions that were not necessarily straightforward (controlling BP that was above target despite other drug treatment); and reflect recommended best practice as described by national guidelines [19]. The behaviours were precisely specified (according to the 'TACT' principle [20]: Target, Action, Context, Time or Who does What, Where and When) in order to provide consistency of measurement across practices and to reduce ambiguity when they were described to survey respondents.

\section{Instrument development and piloting Telephone Interview schedule}

A structured interview schedule was developed to collect details from a nominated study contact in each practice about practices' structures and functions (see Additional File 1) both in general and in relation to the provision of care for patients with type 2 diabetes. The content of the interview schedule was informed by previous studies $[21,22]$, current recommendations for best practice (relating to the organisation of care for people with type 2 diabetes), and expert opinion. Minor amendments were made after the first two practice interviews.

\section{Baseline postal questionnaire Questionnaire development}

The baseline questionnaire consisted of three sections. The first section measured individuals' perceptions relating to team functioning and practice organisational behaviour, and was to be answered by all members of the practice. The second section covered cognitions about performing the six different clinical behaviours, and was to be answered by those members of the practice who provided care for patients with type 2 diabetes. The third section comprised four clinical scenarios relating to patients with type 2 diabetes, and was to be answered by the same group that answered the second section.

The questions covering individuals' perceptions relating to team functioning and practice organisational behaviour (Additional File 2, pages 1 to 8) comprised items based on theoretical constructs within Exchange Theory $[23,24]$, and based on the premise that fair organisations produce well-functioning teams and good health outcomes for patients. The models were a number of existing validated scales: Organizational Justice Evaluation Scale $[25,26]$, a shortened version of the Team Climate Inventory [27], Organisational Citizenship Behaviour [28], and the Job Content Questionnaire (JCQ) (measuring psychological job characteristics including job decision latitude and job demands [26]), (Table 3). Because high job strain, low organizational justice, and low team climate have all predicted a large variety of employee wellbeing and health outcomes, including psychological distress, low involvement, or low citizenship behaviour, these constructs were measured also as potential mediators of the clinical behaviours. Stress was measured using a 12-item measure based on the General Health Questionnaire (GHQ-12) [29]. In

\section{Table 2 The six clinical behaviours}

1. Giving advice about weight management to patients with type 2 diabetes whose BMI is above a target of $30 \mathrm{~kg} / \mathrm{m}^{2}$, even following previous management.

2. Prescribing additional antihypertensive drugs for patients with type 2 diabetes whose blood pressure (BP) is above a target of 140 $\mathrm{mm} \mathrm{Hg}$ for Systolic BP or $80 \mathrm{~mm} \mathrm{Hg}$ for Diastolic BP, even following previous management.

3. Examining foot circulation and sensation in the feet of patients with type 2 diabetes, registered with your practice.

4. Providing advice about self-management to patients with type 2 diabetes, registered with your practice.

5. Prescribing additional therapy for the management of glycaemic control (HbA1c) for the management of HbA1c in patients whose $\mathrm{HbA1 \textrm {c }}$ is higher than $\mathbf{8 . 0 \%}$, despite maximum dosage of two oral hypoglycaemic drugs.

6. Providing general education about diabetes for patients with type 2 diabetes, registered with your practice. 
Table 3 Description of the measures included in the organisational questions of the baseline questionnaire

\begin{tabular}{ll}
\hline Measure & Description (number of questions; scoring) \\
\hline Organisational Justice & $\begin{array}{l}\text { Measures perceived organisational justice and fairness (14; } 1 \text { to 7). } \\
\text { Two dimensions: Procedural Justice (7); Relational Justice (7). }\end{array}$ \\
\hline Team Climate Inventory* & $\begin{array}{l}\text { Measures perceptions of openness to innovation in teams (14; } 1 \text { to 7). Four dimensions: Participation (4); Support for } \\
\text { Innovation (3); Vision (4); Task Orientation (3) }\end{array}$ \\
\hline $\begin{array}{ll}\text { Organisational Citizenship } \\
\text { Behaviour }\end{array}$ & Measures 'extra role behaviours' within the team (13; 1 to 7) \\
\hline Job Content Questionnaire* & $\begin{array}{l}\text { Measures psychological job characteristics (13; } 1 \text { to 7). } \\
\text { Two dimensions: Decision Latitude (9) and Job Demands (4). Decision Latitude is composed of two underlying } \\
\text { dimensions: Skill discretion (6) and Decision Authority (3). }\end{array}$ \\
\hline Stress measure & $\begin{array}{l}\text { Negatively-worded items (6; } 1 \text { to 4) } \\
\text { Positively-worded items (6; } 1 \text { to 4) }\end{array}$ \\
\hline $\begin{array}{l}\text { Self-reported sickness/illness } \\
\text { absence }\end{array}$ & $\begin{array}{l}\text { Free text item } \\
\text { Intention to leave }\end{array}$ \\
\hline * also included as a diabetes specific version
\end{tabular}

* also included as a diabetes specific version

addition, 'diabetes specific' versions of two scales (shortened version of the Team Climate Inventory and the JCQ) were developed in order to explore if they were better predictors of these behaviours than their generic counterparts. These diabetes-specific versions were for completion only by respondents who provided care for patients with type 2 diabetes as part of their routine role within the practice. The questionnaire also included questions about demographic descriptors, the respondent's self-perceived role, who they identified as being involved in delivering care for patients with diabetes in the practice, and two questions covering sickness absence and plans to leave their current job.

The second section of the baseline questionnaire (Additional File 2, pages 9 to 43) comprised items based on theoretical constructs from individual psychological models, including social cognitions models (Theory of Planned Behaviour [30], Social Cognitive Theory [31,32], Learning Theory [33,34], Self Reported Habit Index [35], Action Planning/Coping Planning [36,37]) (Table 4) asking about performing the six different clinical behaviours. The measured constructs from models of motivational factors (individual perceptions about, and attitudes towards, personally performing the six clinical behaviours and their intentions to perform the behaviours) and action factors (including habits, rewards, action plans, coping plans) over the following 12 months. The wording of the items to operationalise the theoretical models was informed by the pilot work undertaken for previous studies by the authors using similar methodology and theoretical models $[4,5,12,38-40]$. We measured intentions in two ways. As well as a traditional strength of intention measure (I intend/plan/expect to < perform behaviour >; score 1 to 7 ), a direct estimate of intention measure was included (Over the next 12 months, given 10 patients < definition of patients $>$, for how many do you intend to $<$ perform behaviour >; score 0 to 10 ), in order to allow us to explore if one or other method of measurement affected the prediction of behaviour.

The third section of the baseline questionnaire included four patient scenarios designed to simulate the behaviour that an individual clinician would perform during a consultation and delivered in a format to simulate the computer screen available during consultations (see pages 33 to 43 Additional File 2). Primary care doctors and nurses were asked whether they would address each of a series of diabetes-related factors, including the six behaviours targeted in the present study, by indicating whether they 'would do' or 'would do if time' address each diabetes-related area of care. The attributes of each scenario were varied, but given the small number of scenarios it was not possible to systematically vary every combination of every variable.

\section{Questionnaire piloting}

Two primary care practices in northeast England took part in piloting the questionnaires. The first section (organisational questions) was piloted with seven administrative staff (practice managers, secretarial and reception staff) and seven healthcare professionals (primary care physicians, practice nurses, and one healthcare assistant). Piloting was by postal survey for all administrative staff and for five clinical staff. Participants were provided with the questionnaire and a stamped addressed envelope to return the questionnaire to the study research associate. They were given written guidance that asked them to complete the questions in their own time, noting how long it took to complete and to comment freely on the clarity and acceptability of the questions. The questions were found to be acceptable, there were no missing responses and the time 
Table 4 Theories, models, and other measures of individual cognitions and attributes and example questions

\begin{tabular}{|c|c|}
\hline $\begin{array}{l}\text { Model, theoretical constructs } \\
\text { (number of questions) }\end{array}$ & Example Item(s) \\
\hline \multicolumn{2}{|l|}{ Theory of Planned Behaviour (TPB) } \\
\hline Attitude (3) & $\begin{array}{l}\text { In my management of patients with diabetes I think it is beneficial to them to 'provide advice about } \\
\qquad \text { weight management.' (scored } 1 \text { to } 7 \text { ) }\end{array}$ \\
\hline Subjective Norm (2) & $\begin{array}{l}\text { In my management of patients with diabetes I am expected to 'provide advice about weight } \\
\text { management.' (scored } 1 \text { to } 7 \text { ) }\end{array}$ \\
\hline Perceived Behavioural Control (2) & $\begin{array}{l}\text { In my management of patients with diabetes I am confident that I can 'provide advice about weight } \\
\text { management.' (scored } 1 \text { to } 7 \text { ) }\end{array}$ \\
\hline Intention (3) & $\begin{array}{l}\text { In my management of patients with diabetes I intend to 'provide advice about weight management.' } \\
\text { (scored } 1 \text { to } 7 \text { ) }\end{array}$ \\
\hline Direct estimate of Intention (1) & $\begin{array}{c}\text { Over the next } 12 \text { months, given } 10 \text { patients 'whose BMI is above target,' for how many do you intend to } \\
\text { 'provide advice about weight management.' (Scored } 0 \text { to 10) }\end{array}$ \\
\hline \multicolumn{2}{|l|}{ Social Cognitive Theory (SCT) } \\
\hline Outcome expectancies (3) & $\begin{array}{l}\text { In my management of patients with diabetes I think it is good practice to 'provide advice about weight } \\
\text { management.' (scored } 1 \text { to } 7 \text { ) }\end{array}$ \\
\hline $\begin{array}{l}\text { Self Efficacy: } \\
\text { Clinical behaviour: } 1 \text { (10); } 2 \text { (9); } 3 \text { (8);(9); } \\
5 \text { (8); } 6 \text { (11) }\end{array}$ & $\begin{array}{l}\text { I am confident that I can 'provide advice about weight management' to any patient whose BMI is above } \\
\text { target even when 'the patient's BMI has been stable for five years.' (scored } 1 \text { to } 7 \text { ) }\end{array}$ \\
\hline \multicolumn{2}{|l|}{ Learning Theory (OLT) } \\
\hline Anticipated consequences (3) & $\begin{array}{l}\text { In my management of patients with diabetes 'whose BMI is above target.'.. overall, it is highly likely } \\
\text { that they will be worse off if I 'provide advice about weight management.' (scored } 1 \text { to 7) }\end{array}$ \\
\hline Evidence of habitual behaviour (2) & $\begin{array}{c}\text { In my management of patients with diabetes 'whose BMI is above target.'.. it is my usual practice to } \\
\text { 'provide advice about weight management.' (scored } 1 \text { to } 7 \text { ) }\end{array}$ \\
\hline Self-reported Habit Index (SRHI) (12) & $\begin{array}{l}\text { Providing advice about weight management to patients whose BMI is above target is something that 'I } \\
\text { do frequently.' (scored } 1 \text { to } 7 \text { ) }\end{array}$ \\
\hline \multicolumn{2}{|l|}{ Action planning/coping planning } \\
\hline Action planning (3) & I have a clear plan of 'how I will' 'provide advice about weight management.' (scored 1 to 7) \\
\hline $\begin{array}{l}\text { Coping planning: } \\
\text { Clinical behaviour: } 1 \text { (10); } 2 \text { (9); } 3(4) ; 4 \\
\text { (9); } 5 \text { (8); } 6 \text { (11) }\end{array}$ & $\begin{array}{l}\text { I have made a clear plan regarding 'providing advice about weight management to patients whose BMI is } \\
\text { above target if ...' 'the patient's BMI has been stable for five years' (scored } 1 \text { to } 7 \text { ) }\end{array}$ \\
\hline Past behaviour (1) & $\begin{array}{c}\text { Over the past } 12 \text { months, for approximately how many of the last } 10 \text { patients with diabetes 'whose BMl } \\
\text { was above target' did you 'provide advice about weight management' (scored } 0 \text { to 10). }\end{array}$ \\
\hline Demographics & Gender, years qualified, trainer status, sessions worked per week; role within primary care practice; job title \\
\hline
\end{tabular}

taken to complete the instrument varied from seven to 25 minutes (median 20 minutes). No adjustments were made to the questions following piloting.

The second and third sections were initially piloted using postal methods as described above with one primary care physician and two practice nurses. One lead primary care physician for diabetes and one diabetes specialist nurse also piloted the questionnaire during a face-to-face session with the study research associate using 'think aloud' technique [41]. Based on the feedback received and concerns expressed during the 'think aloud' sessions, adjustments were made to minimise repetition in the wording of the items, and two behavioural scenarios (see Measures of behaviour below) were removed (leaving four in the final version) to shorten the questionnaire and to keep the completion time within an estimated maximum of two hours. The amended questionnaire was then re-piloted using postal methods with the two original 'think aloud' participants and an additional two primary care physicians and two practice nurses. No further amendments were suggested as a result of the re-piloting. All pilot participants received book vouchers ( $£ 10$ for administrative staff, $£ 20$ for nursing staff, and $£ 50$ for doctors) for returning a completed questionnaire.

\section{Twelve-month self-reported behaviour questionnaire}

A 'self-reported behaviour' questionnaire, asked individual clinicians about their performance of each of the six clinical behaviours over the previous 12 months (see Additional File 3: Self Reported behaviour questionnaire). The items used in this very brief questionnaire (one item for each of the six clinical behaviours) were worded: Over the past 12 months, given 10 patients with diabetes < attributes of patients $>$, for how many did you < perform behavior $>$ ? (scored 0 to 10). Such measures of behaviour are commonly used and are well predicted by social cognition models [2]. 


\section{Instrument administration Telephone interview}

Data were collected between March and August 2008 during a 30-minute telephone interview with a nominated study contact (practice manager, practice research nurse, or a general practitioner lead for diabetes) at each of the recruited primary care practices. The study contact was sent a summary of the data collected for verification and asked to check with practice colleagues as necessary if they were uncertain about the accuracy of the data provided.

\section{Baseline postal questionnaire survey}

The baseline postal questionnaire survey ran between September and December 2008. All the questionnaires for a practice were delivered to the nominated study contact in the practice who then distributed the questionnaires to practice colleagues. All participants were provided with written information about the study, asked to complete their questionnaires individually, and provided with a pre-paid envelope to return their questionnaire directly to the study research associate. Reminders were sent to non-responders at two and four weeks. Individuals not wishing to complete the study questionnaire and who wanted this to be confidential from their practice colleagues were given the option of returning a blank questionnaire.

\section{Twelve-month self-reported behaviour questionnaire survey}

This was administered 12 months after the baseline questionnaire and using the same method as described above.

\section{Measures of behaviour}

Five different, complementary measures of the performance of the six study behaviours were collected. The first two provide individual level measures of behaviour, while the latter three give aggregated practice level behavioural data.

\section{Simulated behaviour}

This 'simulated behaviour' measure derived from clinical scenarios (described above) provided the first of two measures of individual clinicians' self-reported performance of the six study behaviours. Clinicians could endorse that they 'would do' (score 2) or 'would do if time' (score 1) each behaviour plus add explanatory text. Scores for one of the simulated behaviours were adjusted to reflect current best practice-prescribing additional drug therapy for the management of HbA1c was, at the time of the study, advised for individuals whose HbA1c was above $8.0 \%$. Therefore, for scenarios in which the simulated patient's HbA1c was $\leq 8.0 \%$, the correct decision was not to prescribe additional therapy, and respondents who did not indicate that they would act on this were credited with having made the evidence-based decision.

\section{Clinician self-reported behaviour}

The 12-month self-reported behaviour questionnaire (described above) provided the second measure of individual clinicians' self-reported performance of the six study behaviours.

\section{Clinician behaviour based on data extracted from practice computer systems}

Anonymised individual patient biochemical, physiological, and drug data were extracted from practice computer systems for all patients with a diagnosis of type 2 diabetes registered with the practice (see Additional File 4: List of Read Codes for the data items). For each of the computer systems used by the practices, search queries were written by an experienced National Health Service (NHS) performance data manager. Data were extracted for a 25-month period (i.e., 12 months prior to and 12 months after the month within which the baseline survey was launched). The search queries were sent to each practice along with written guidance on running the query, a process that practices were familiar with. The performance data manager also provided practices with telephone and email support if needed.

\section{Patient-report of clinicians' behaviour}

We anticipated that information on some of the study behaviours of interest might be recorded poorly, if at all, in the computer records, specifically those on the provision of advice on weight management, self-management, and general education. A single relevant question about each was included in a patient satisfaction questionnaire previously used by the Healthcare Commission [42]. In order to increase the specificity of the measure, as well as the single item, we identified additional items that assessed specific aspects of each behaviour with the aim of producing a composite score for each behaviour. We examined the internal consistencies and ran principle components analyses on the items within each behaviour and then across behaviours. Performance of foot examination was also asked about and so provided an additional, single item, measure of this behaviour.

Using a single posting, anonymous (to the research team) survey (for the questionnaire see Additional File 5 ), we asked patients in the study practices about their experiences of their clinicians providing advice about weight management, self-management, and general education about their diabetes. Aiming to achieve a final sample size of 25 respondents per practice, 86 practices approached 100 randomly selected patients anticipating 
a 25\% response rate. Questionnaires were distributed from the practice and returned to the study research associate.

\section{Quality and outcomes framework data}

The Quality and Outcomes Framework (QOF) is a voluntary annual reward and incentive programme for all primary care practices in UK, detailing practice performance across a number of clinical areas (of which diabetes mellitus is one) plus organisational areas $[43,44]$. The data are extracted from practice computer systems by the local primary healthcare administrative authority on an annual basis using a standard data extraction query. The data are publically available and QOF data on the diabetes and organisational domains were obtained from the NHS Information Centre http:// www.ic.nhs.uk/. The QOF data for diabetes mellitus and practice organisation were collected for each of the participating practices for the 12-month period of QOF data collection (May 2008 to April 2009) that best matched the 12-month period after baseline questionnaire completion. Where available, practice level numerators and denominators were obtained for diabetes mellitus indicators and percentage achievement levels were calculated; where they were not available, the calculated point score is reported.

\section{Ethics approval}

The study was approved by Newcastle and North Tyneside 2 Research Ethics Committee, REC reference number $07 / \mathrm{H} 0907 / 102$.

\section{Results}

\section{Recruitment and instrument response rates}

The process of recruitment of primary care practices is shown in Figure 1. The initial invitation went to all GPRF practices in Scotland, Wales, Northern Ireland, and a random sample of practices in England up to a total of 500 practices. One hundred practices were recruited and all took part in the telephone interview, baseline, and follow-up phases of the study. One practice was subsequently excluded from all analyses due to low completion rates for all data collection; we subsequently report on 99 practices. All practices completed a telephone interview. Informants were GPs for 47 practices, nurses for 37 practices and the practice manager for 15 practices. All practices were invited to verify their data summaries and 75 did so.

The baseline questionnaire (organisational questions) was sent to all clinical and administrative staff (2,079 in total). Usable completed questionnaires were returned by $946 / 1,236(76.5 \%)$ administrative staff, $423 / 529$ (80.0\%) primary care doctors, and 255/314 (81.2\%) nurses (see Figure 2). One thousand and fifty-five staff members indicated that providing care for patients with diabetes was part of their routine role and 890/1,055 $(84.4 \%)$ went on to complete the diabetes-specific versions of the measures in the questionnaire.

The baseline questionnaire (clinical questions) was sent to all clinical staff within each of the 99 practices (843 in total). Of clinicians who indicated that they were involved in providing diabetes care, usable completed questionnaires were returned by 326/361 (90.3\%) primary care doctors and 163/186 (87.6\%) nurses (see Figure 2 ). Three hundred and ten primary care doctors and 162 primary care nurses responded to at least one area of care in every clinical scenario. Table 5 presents the practice level response rates for the two baseline questionnaires by staff type (excluding 146 questionnaires that were returned blank). We achieved $100 \%$ overall response rates from clinicians in 40 practices and achieved responses from over $80 \%$ of clinicians in 67 practices. We achieved $100 \%$ response from $38 \%$ of practices for at least one of the generic organisational questionnaires and from $84 \%$ of practice for at least one of the two diabetes-specific organisational questionnaires. Sixty percent of practices had a $100 \%$ response for questions on at least one individual-level psychological model.

The follow-up questionnaire was sent to 843 clinical staff. Six hundred and ninety-four (82.3\%) completed questionnaires were returned. Of those involved in providing diabetes care, 427/547 (78.1\%) could be paired with a completed baseline clinical questionnaire (see Figure 2).

Practices were supplied with a total of 8,600 patient questionnaires. Given the anonymous nature of the survey and the fact that practices with less than 100 patients with diabetes will have sent out fewer questionnaires a precise response rate cannot be calculated. A total of 3,591 analysable questionnaires were received (41.8\% return rate).

\section{Study practices}

Seventy-four of the recruited practices were located in England, 13 in Scotland, four in Wales, and eight in Northern Ireland. Thirty-seven were rural practices and 62 were urban; 15 had branch surgeries (range 2 to 5 sites); 18 were dispensing practices; 62 were training practices. The mean (SD) patient list size was 7,431 $(4,040)$, with a mean (SD) proportion of patients aged over 65 years of $18 \%$ (7\%). Most practices served patients of mainly 'White British' origin (84/99), and 63 practices 'never' or 'rarely' used interpreters. Tables 6 and 7 summarise the structural and functional characteristics of the study practices, both in general and in relation to diabetes care. There was a mean (SD) of 5.4 (2.7) doctors per practice covering a mean (SD) of 36.4 


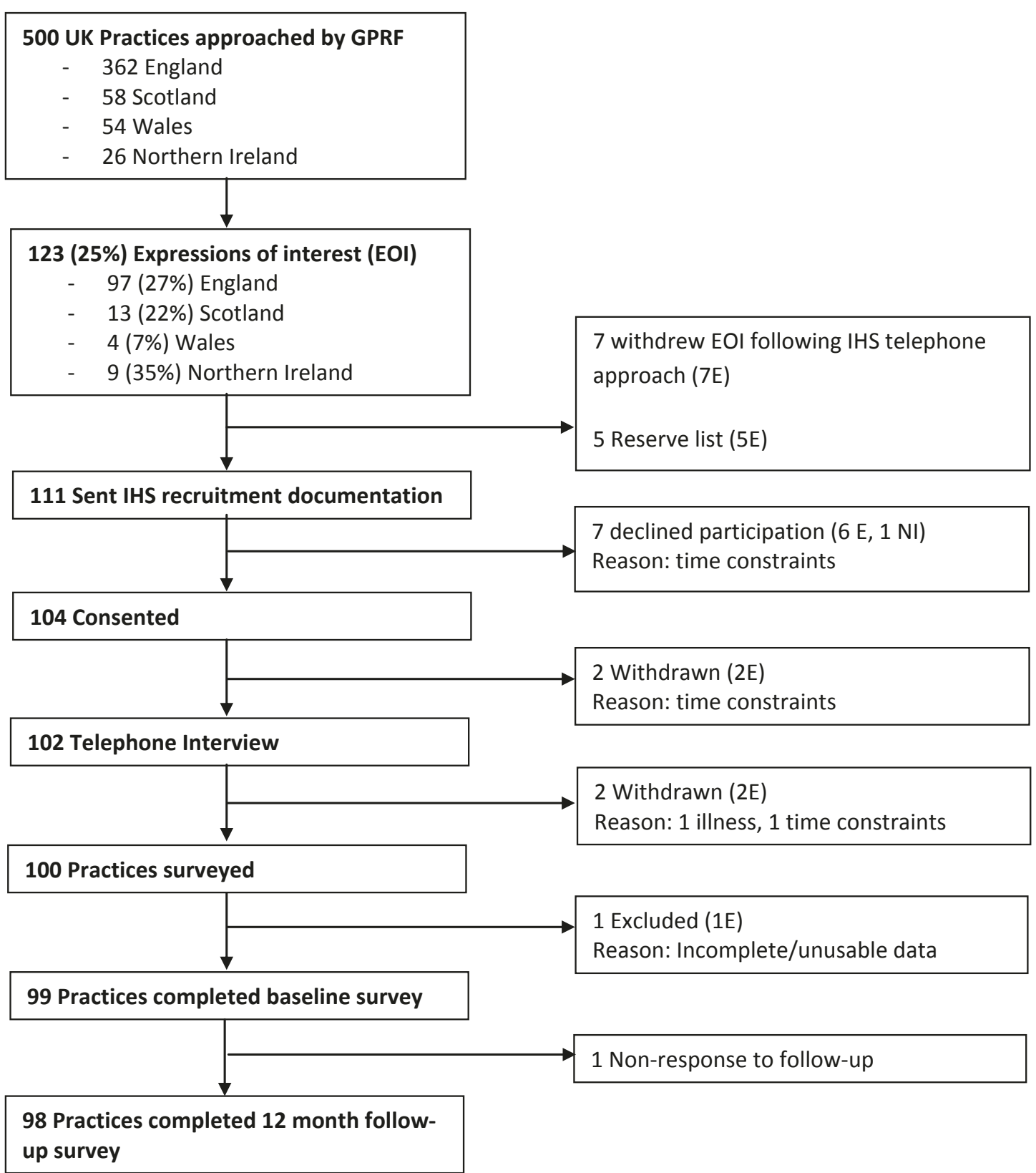

Figure 1 Flowchart of the recruitment of primary care practices recruited to the iQuaD study.

(20) half-day (notionally 3.5 hour) sessions and providing a mean (SD) of 515 (315) appointments per week. Similarly 3.1 (1.6) nurses per practice offered 17.7 (10.5) half-day sessions. Though only compared descriptively, study practices were of an equivalent size to MRC GPRF practices overall (mean list size 7,696). Since devolution in 1998, comparative UK data is hard to find but, compared to all general practices in England, the study practices were larger and had more doctors (2007 England mean list size: 6,487; mean number of practitioners per partnership: 4) and, at $4 \%$, the study sample also contained a low proportion of single-handed practices [45].

Questionnaire results descriptive data Baseline organisational questionnaire

Table 8 presents alphas for internal consistency of the measures included in the organisational questionnaire and the mean (SD) scores for each measure and for both general and diabetes specific organisational measures. The internal consistencies were all acceptable, with alpha coefficients ranging from 0.61 to 0.97 and 


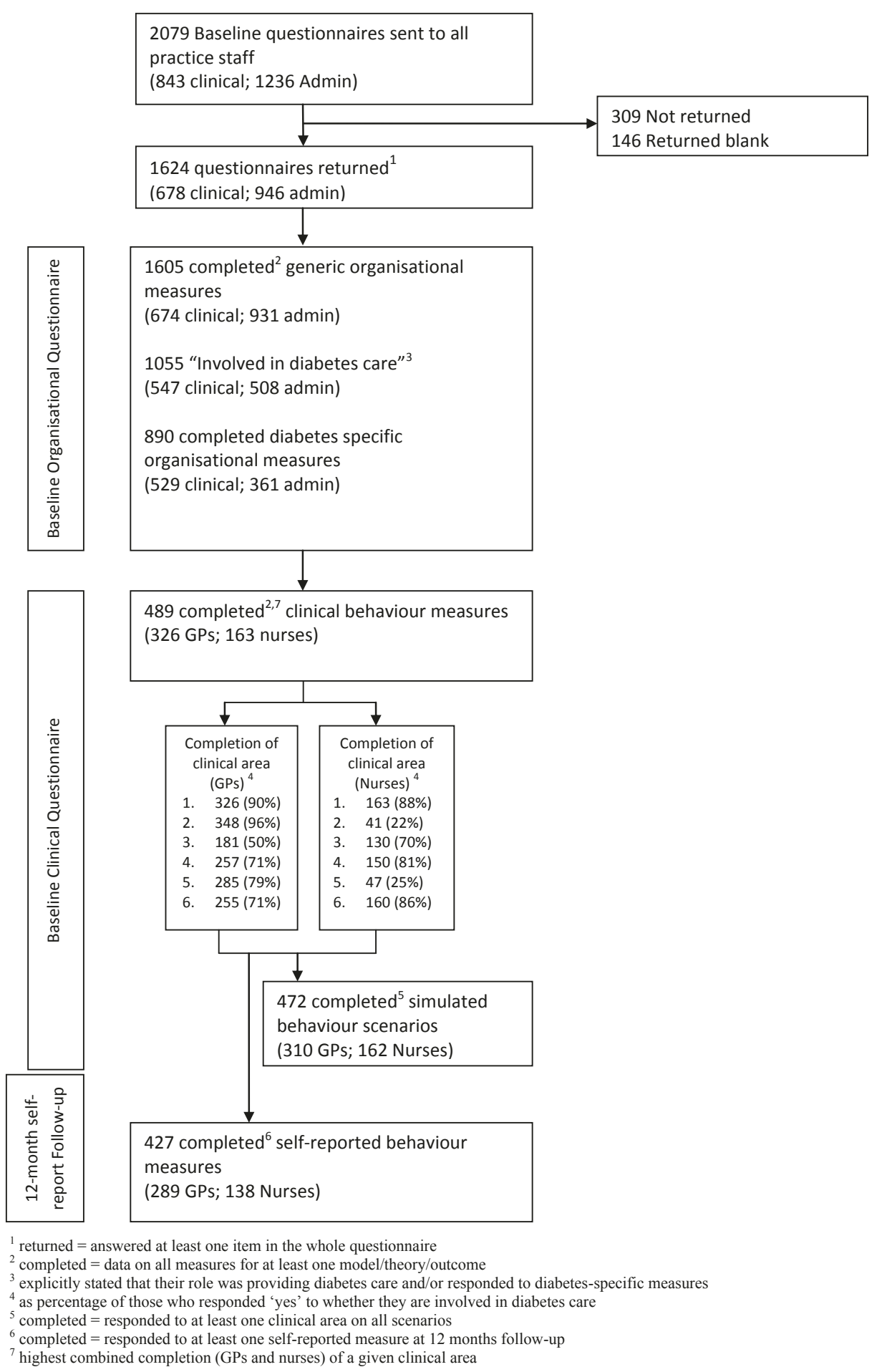

Figure 2 Flowchart of individual clinicians and administrative staff from the 99 practices recruited to the iQuaD study.

Pearson correlation coefficient (used for two item measures) from 0.32 to 0.81 . Although the Team Climate Inventory has not been widely used in UK primary care [46], the scores are very similar to those from a recent
UK study which reported values from 14 practices in South Tyneside [47]. For scores on constructs in the Job Control Model, the internal consistencies ranged from 0.61 to 0.78 , compatible with the range of previously 
Table 5 Individual level and practice level response rates

\begin{tabular}{|c|c|c|c|c|c|c|c|c|}
\hline \multirow[b]{2}{*}{ Staff } & \multirow[b]{2}{*}{ Questionnaire } & \multirow{2}{*}{$\frac{\text { Individual level response rate }}{\mathrm{N}(\%)}$} & \multicolumn{6}{|c|}{ Practice level response rates } \\
\hline & & & $100 \%$ & $90-99 \%$ & $80-89 \%$ & $70-79 \%$ & $50-69 \%$ & $<50 \%$ \\
\hline Overall & Any & $1624 / 2079(78.1)$ & 18 & 18 & 32 & 8 & 16 & 7 \\
\hline \multirow[t]{4}{*}{ Clinicians } & Any & $678 / 843(80.4)$ & 40 & 9 & 18 & 9 & 15 & 8 \\
\hline & Organisational (generic) & $674 / 843(80.0)$ & 38 & 8 & 20 & 9 & 16 & 8 \\
\hline & Organisational (diabetes) & $529 / 547(96.7)$ & 84 & 2 & 6 & 3 & 3 & 1 \\
\hline & Clinical & 489/547 (89.4) & 60 & 3 & 13 & 9 & 13 & 1 \\
\hline \multirow[t]{3}{*}{$\overline{\text { Admin }}$} & Any & $946 / 1236(76.5)$ & 25 & 15 & 24 & 11 & 14 & 10 \\
\hline & Organisational (generic) & $931 / 1236(75.3)$ & 22 & 13 & 26 & 10 & 18 & 10 \\
\hline & Organisational (diabetes) & $361 / 508(71.1)$ & 27 & 1 & 12 & 21 & 25 & 13 \\
\hline
\end{tabular}

reported values (0.68 to 0.82$)$ [48]. The diabetes specific versions of these two measures were scored very similarly. Scores across the other scales were well into the positive range of responses; for measures on a 1 to 7 scale the median (inter-quartile range) score was 5.32 (5.28 to 5.58). Table 8 also shows rates self-reported episodes and days of sickness and intention to leave. Sickness rates were low (mean number of days lost per year was just over two) and highly skewed with a small number of respondents reporting higher rates of sickness. The table also includes intention to leave with just over $8 \%$ of staff reported intending to leave.

\section{Baseline clinical questionnaire}

Table 9 presents the mean (SD) scores and internal consistency for each theoretical construct included in the clinical questionnaire. The internal reliability measures are all acceptable. Across the six behaviours, the scores for the constructs were all generally well towards the positive end of the seven point scoring scale. For each of the theories the median (range across behaviours) was:

- Theory of Planned Behaviour: Attitude 6.2 (5.7, 6.4), Subjective Norm 5.7 (5.6, 5.9), Perceived Behavioural Control $5.3(5.1,5.6)$, Intention Strength $5.7(5.5,6.1)$, Intention (direct estimation, 0-10) 8.0 (7.4, 9.0).

- Social Cognitive Theory: Outcome Expectancies 6.2 (5.7, 6.4), Self-Efficacy $5.0(4.6,5.7)$, Proximal Goals 5.7 $(5.5,6.1)$.

- Learning Theory: Anticipated Consequences 6.3 (5.8, 6.5), Evidence of habitual behaviour $5.6(5.4,5.9)$.

Table 6 Summary data of the general functional and structural characteristics of the practices

\begin{tabular}{|c|c|}
\hline Functional Characteristics & Staff levels (mean (SD)) \\
\hline Primary care doctors & 5.4 (2.7); Partners 4.2 (2.2); sessions covered 36.4 (20.0); appointments per week 515 (345) \\
\hline Primary care nurses & 3.1 (1.6); sessions covered 17.7 (10.5) \\
\hline $\begin{array}{l}\text { At least one GP or nurse with } \\
\text { diploma training }\end{array}$ & $\begin{array}{c}26 \text { have both GP and a nurse; } 8 \text { have only a GP; } 15 \text { have only a nurse; } 23 \text { have neither a GP nor a nurse; } 27 \\
\text { not reported }\end{array}$ \\
\hline Healthcare Assistants & $1.1(0.9) ;$ sessions covered $7.1(8.8)$ \\
\hline $\begin{array}{l}\text { Number of reception/ } \\
\text { administrative staff }\end{array}$ & $11.7(6.7)$ \\
\hline \multicolumn{2}{|l|}{ Staff turnover } \\
\hline Clinical staff (GPs and Nurses) & $\begin{array}{c}15 \text { practices reported turnover of up to two clinical staff members in the previous twelve months. In all } \\
\text { practices these had been replaced. }\end{array}$ \\
\hline Admin staff (all clerical and admin) & $\begin{array}{c}61 \text { practices reported turnover of up to two admin staff members in the previous twelve months. In all but } 5 \\
\text { practices these had been replaced. }\end{array}$ \\
\hline \multicolumn{2}{|l|}{ Meetings } \\
\hline Practice & Held by 83 practices; monthly* for 1.5 hours; majority (52) include all practice staff \\
\hline Partner & $\begin{array}{l}\text { Held by } 75 \text { practices; monthly* for } 1.5 \text { hours; } 27 \text { GPs only; } 48 \text { included other staff, but most frequent } \\
\text { combination was partners and practice manager (36). }\end{array}$ \\
\hline Clinical meetings & Held by 71 practices; monthly* for one hour; 44 exclusively for clinical staff; 27 included non-clinical staff \\
\hline Administrative meetings & Held by 66 practices; quarterly* for one hour; 66 include all admin staff. \\
\hline Educational meetings & $\begin{array}{l}\text { Held by } 83 \text { practices; } 39 \text { at least monthly and } 36 \text { at least quarterly, remainder bi-annual or annual, duration } \\
\text { varied from one hour to protected half-day sessions: } 44 \text {, all staff attend; 33, clinical staff only }\end{array}$ \\
\hline
\end{tabular}


Table 7 Summary data of the (Type 2) diabetes related functional and structural characteristics of the practices

\begin{tabular}{|c|c|}
\hline Structure of care provision & $\mathrm{N}$, frequency/service provider \\
\hline Dedicated diabetes clinic & 71 practices \\
\hline Frequency; duration & 43, weekly; 14 , monthly; $14, \mathrm{n} / \mathrm{r}^{*} ; 1$ to 2 half-day sessions \\
\hline Appointment length & Most frequently 20 to 30 mins \\
\hline Who leads management? & 16, doctor; 49, nurse; 6, co-managed by doctor and nurse \\
\hline Admin support & 29 , dedicated member of admin team; 37 , general admin team, 1, none; $4, n / r$ \\
\hline Doctor available (if required) at clinic & 69 , diabetes lead doctor; 30, Patient's own or duty doctor \\
\hline Other staff available at clinic & 9, Diabetes specialist nurse; 16 , dietician \\
\hline Seen in routine appointments & 28 practices \\
\hline Appointment length & Most frequently 20 ro $30 \mathrm{mins}$ \\
\hline Who leads management? & 8, doctor; 19, nurse; 1, co-managed by doctor and nurse \\
\hline Admin support & 11, dedicated member of admin team; 13 , general admin team' $4, n / r$ \\
\hline \multicolumn{2}{|l|}{ General management of patients } \\
\hline Routine recall interval & 61, annual review; 34, 6-month review; 4, 3-month review \\
\hline Who organizes recall? & 58, admin support; 36 , nurse; 5, GP \\
\hline Blood tests & 77 , done in advance; 22 , done on day of visit \\
\hline Patient sees doctor routinely at review & 43, always for Annual review; 56, only 'if indicated' for any review \\
\hline Insulin initiation & 50 , in-house ( 16 by doctor, 26 by practice nurse, 6 by DSN**; $2, n / r) ; 49$, in Secondary Care only \\
\hline Patients on insulin managed in practice & 60 , yes, only if stable on insulin; 39 , secondary care only \\
\hline Foot inspection & 58 , in-house; 17 , referred to podiatry services; 24 , not reported \\
\hline Use of guidelines for diabetes & $\begin{array}{l}\text { 53, both national (most frequently NICE***) and local guidelines; 33, national guidelines only; } 9 \text {, local } \\
\text { guidelines only; 4, do not use guidelines }\end{array}$ \\
\hline
\end{tabular}

\section{Patient education}

Availability of Structured Patient Education 25, secondary care; 37, primary care: 4, location not specified. 33, no structured programme available Programme

Practice provision of patient education $\quad 26$, provide 'in-house' education only; 73, refer patients for external education: 36, 'structured programme' (most commonly DESMOND); 37, refer to locally developed educational sessions.

Who provides in-house education 75, nurse-led; 5, doctor-led; 19 , shared

Materials $\quad 55$, use in-house leaflets; 68, use DUK $K^{* * *}$ leaflets; 11, use PCT leaflets.

39, refer patients to DUK website; 5, refer patients to local website; 6 , refer patients to in-house website

\section{Management aids}

\begin{tabular}{|c|c|}
\hline Diaries & 67 , use patient diaries; 20 , do not use diaries; $12, \mathrm{n} / \mathrm{r}$ \\
\hline Blood testing kits & $\begin{array}{l}\text { 40, use with all patients/patients who request kits; } 20 \text {, use only with patients on insulin; } 9 \text {, do not use; } \\
24, n / r\end{array}$ \\
\hline Urine testing kits & $\begin{array}{l}\text { 21, use with all patients/patients who request kits; } 5 \text {, use only with patients on insulin; } 41 \text {, do not use; } \\
32, \mathrm{n} / \mathrm{r}\end{array}$ \\
\hline \multicolumn{2}{|l|}{$\begin{array}{l}\text { Access to specialist support services } \\
\text { outside of the practice }\end{array}$} \\
\hline Diabetes Specialist Nurse & 53 , via secondary care; 28, primary care; $18, \mathrm{n} / \mathrm{a}^{* * * * *}$ \\
\hline GPwSI (in Diabetes) & 6 , via secondary care; 14 , primary care; $79, \mathrm{n} / \mathrm{a}$ \\
\hline Dietician & 40 , via secondary care; 17 , primary care; $42, n / a$ \\
\hline Podiatrist & 32 , via secondary care; 30 , primary care; $37, n / a$ \\
\hline Retinal Screening & 29 , via secondary care; 36 , primary care; $34, \mathrm{n} / \mathrm{a}$ \\
\hline Diabetes Centre in Secondary Care & 23 , available to consult for advice \\
\hline Specialist Diabetologist & 44, available to consult for advice \\
\hline
\end{tabular}

${ }^{*} \mathrm{n} / \mathrm{r}$ not reported; **Diabetes Specialist Nurse; ${ }^{* * *}$ National Institute of Health and Clinical Excellence; ${ }^{* * *}$ Diabetes UK; ${ }^{* * * *} \mathrm{n} / \mathrm{a}$ not available 
Table 8 Internal consistency means and standard deviations of scores for team function and organisational behaviour measures, for general and diabetes specific measures and illness sickness absence and intention to leave

\begin{tabular}{|c|c|c|c|c|c|c|c|c|}
\hline \multirow[b]{2}{*}{ Constructs } & \multirow[b]{2}{*}{ Dimensions } & \multirow[b]{2}{*}{$\begin{array}{c}\mathrm{N} \\
\text { (items) }\end{array}$} & \multicolumn{3}{|c|}{ GPs and nurses } & \multicolumn{3}{|c|}{ Administrative staff } \\
\hline & & & $\mathrm{N}$ & $\begin{array}{c}\text { Internal } \\
\text { consistency }{ }^{1}\end{array}$ & Mean (SD) & $\mathrm{N}$ & $\begin{array}{c}\text { Internal } \\
\text { consistency }{ }^{1}\end{array}$ & Mean (SD) \\
\hline \multirow[t]{2}{*}{ Organisational Justice } & Procedural Justice & 7 & 668 & 0.93 & $5.25(0.92)$ & 924 & 0.96 & $5.30(1.13)$ \\
\hline & Relational Justice & 7 & 672 & 0.92 & $5.80(0.81)$ & 923 & 0.95 & $5.30(1.10)$ \\
\hline Team Climate (TCI) & Participation & 4 & 677 & 0.92 & $5.73(1.07)$ & 940 & 0.93 & $5.28(1.21)$ \\
\hline \multirow[t]{3}{*}{ (Generic) } & $\begin{array}{l}\text { Support for } \\
\text { Innovation }\end{array}$ & 3 & 675 & 0.88 & $5.30(1.07)$ & 937 & 0.93 & $5.17(1.22)$ \\
\hline & Vision & 4 & 675 & 0.86 & $5.63(0.78)$ & 920 & 0.93 & $5.30(1.14)$ \\
\hline & Task Orientation & 3 & 675 & 0.87 & $5.33(1.01)$ & 930 & 0.89 & $5.15(1.15)$ \\
\hline Team Climate (TCI) & Participation & 4 & 533 & 0.92 & $5.62(1.03)$ & 379 & 0.94 & $5.40(1.14)$ \\
\hline \multirow[t]{3}{*}{ (Diabetes-specific) } & $\begin{array}{l}\text { Support for } \\
\text { Innovation }\end{array}$ & 3 & 533 & 0.92 & $5.23(1.14)$ & 379 & 0.95 & $5.38(1.17)$ \\
\hline & Vision & 4 & 532 & 0.84 & $5.67(0.81)$ & 360 & 0.94 & $5.48(1.07)$ \\
\hline & Task Orientation & 3 & 532 & 0.89 & $5.28(1.03)$ & 358 & 0.91 & $5.22(1.19)$ \\
\hline $\begin{array}{l}\text { Organisational Citizenship } \\
\text { Behaviour }\end{array}$ & & 13 & 671 & 0.91 & $5.61(0.80)$ & 926 & 0.92 & $5.40(0.93)$ \\
\hline Job content Questionnaire & Decision Latitude & 9 & 674 & 0.73 & $\begin{array}{c}99.01 \\
(10.79)\end{array}$ & 933 & 0.78 & $\begin{array}{c}82.28 \\
(15.85)\end{array}$ \\
\hline \multirow[t]{3}{*}{ (Generic) } & Skill Discretion & 6 & 674 & 0.61 & $48.76(4.87)$ & 933 & 0.67 & $39.14(7.55)$ \\
\hline & Decision Authority & 3 & 674 & 0.70 & $50.24(7.61)$ & 933 & 0.76 & $\begin{array}{c}43.14 \\
(10.55)\end{array}$ \\
\hline & Job Demands & 4 & 674 & 0.73 & $44.59(8.14)$ & 933 & 0.70 & $42.66(8.24)$ \\
\hline Job content Questionnaire & Decisional Latitude & 9 & 529 & 0.77 & $\begin{array}{c}94.85 \\
(12.27)\end{array}$ & 361 & 0.78 & $\begin{array}{l}75.82 \\
(16.55)\end{array}$ \\
\hline \multirow[t]{3}{*}{ (Diabetes-specific) } & Skill Discretion & 6 & 529 & 0.68 & $46.73(5.68)$ & 361 & 0.71 & $37.31(8.25)$ \\
\hline & Decision Authority & 3 & 529 & 0.69 & $48.12(8.40)$ & 361 & 0.68 & $\begin{array}{c}38.51 \\
(10.67)\end{array}$ \\
\hline & Job Demands & 4 & 529 & 0.75 & $42.36(8.56)$ & 361 & 0.71 & $39.31(9.22)$ \\
\hline Stress (negative items) & & 6 & 663 & 0.83 & $1.96(0.41)$ & 912 & 0.83 & $1.95(0.48)$ \\
\hline$\underline{\text { Stress (positive items) }}$ & & 6 & 662 & 0.81 & $2.12(0.36)$ & 926 & 0.77 & $2.14(0.38)$ \\
\hline \multirow[t]{2}{*}{ Self-reported sickness/illness } & $\begin{array}{l}\text { Episodes (mean } \\
\text { (range)) }\end{array}$ & 1 & 651 & $\mathrm{n} / \mathrm{a}$ & $0.55(0 ; 6)$ & 858 & $\mathrm{n} / \mathrm{a}$ & $0.80(0 ; 6)$ \\
\hline & Days (mean (range)) & 1 & 632 & n/a & $2.16(0 ; 60)$ & 823 & $\mathrm{n} / \mathrm{a}$ & $2.62(0 ; 62)$ \\
\hline Intention to leave & \% responding 'yes' & 1 & 662 & $\mathrm{n} / \mathrm{a}$ & $8.16 \%$ & 889 & $\mathrm{n} / \mathrm{a}$ & $8.77 \%$ \\
\hline
\end{tabular}

All scales scored 1 to 7 except Stress which is scored 1 to 4 (Much less than usual, Same as usual, More than usual, Much more than usual) and JCQ recoded from 1 to 7 to 1 to 5 .

- Action Planning 5.8 (5.4, 6.2), Coping Planning 4.7 $(4.5,5.5)$.

Within the theories, whilst overall no Theory of Planned Behaviour construct was scored below five, the control item had the lowest scores across all six behaviours, a similar pattern to the self-efficacy item scores within Social Cognitive Theory suggested that clinicians had stronger motivational than action cognitions. Coping planning was scored lower than action planning for all six behaviours, suggesting that clinicians were clearer how to initiate behaviours than to cope with problems should their initial plans not succeed.

Intention (measured either as strength of intention or direct estimation) to perform the behaviour was highest for 'giving advice about weight management' and was lowest for 'prescribing additional anti-hypertensive drugs' (strength of intention) and 'foot examination' (direct estimation). The highest habit score was also for 'giving advice about weight management' and the lowest was for 'prescribing additional anti-hypertensive drugs.' For action planning and coping planning the highest scores were both for 'foot examination'; the lowest action planning score was for 'giving advice about selfmanagement' and the lowest coping plan score for 'giving advice about weight management.'

\section{Measures of behaviour \\ Behaviour simulation}

The proportion of clinicians reporting that they 'would do' or 'would do if time' each behaviour by scenario is 
Table 9 Internal consistency, means and standard deviations of scores for predictive clinical measures, by theoretical and conceptual model, for each of the six clinical behaviours

\begin{tabular}{|c|c|c|c|c|c|c|c|c|c|c|}
\hline \multirow[b]{2}{*}{ Model } & \multirow[b]{2}{*}{ Constructs } & \multicolumn{3}{|c|}{$\begin{array}{l}\text { Behaviour 1: Providing weight } \\
\text { management advice }\end{array}$} & \multicolumn{3}{|c|}{$\begin{array}{l}\text { Behaviour 2: Prescribing } \\
\text { additional antihypertensive drugs }\end{array}$} & \multicolumn{3}{|c|}{$\begin{array}{l}\text { Behaviour 3: Examining feet } \\
\text { (circulation) })^{2}\end{array}$} \\
\hline & & $\begin{array}{c}\mathrm{N} \\
\text { items }\end{array}$ & $\begin{array}{c}\text { Internal } \\
\text { consistency }{ }^{1}\end{array}$ & $\begin{array}{c}\text { Mean } \\
(\mathrm{SD})\end{array}$ & $\begin{array}{c}\mathrm{N} \\
\text { items }\end{array}$ & $\begin{array}{c}\text { Internal } \\
\text { consistency }{ }^{1}\end{array}$ & $\begin{array}{c}\text { Mean } \\
\text { (SD) }\end{array}$ & $\begin{array}{c}\mathrm{N} \\
\text { items }\end{array}$ & $\begin{array}{c}\text { Internal } \\
\text { consistency }{ }^{1}\end{array}$ & $\begin{array}{c}\text { Mean } \\
\text { (SD) }\end{array}$ \\
\hline \multirow[t]{5}{*}{ TPB } & Attitude & 3 & 0.72 & $\begin{array}{l}6.27 \\
(0.78)\end{array}$ & 3 & 0.95 & $\begin{array}{c}5.71 \\
(1.04)\end{array}$ & 3 & 0.70 & $\begin{array}{c}6.13 \\
(1.01)\end{array}$ \\
\hline & Subjective norm & 2 & 0.42 & $\begin{array}{l}5.92 \\
(0.98)\end{array}$ & 2 & 0.59 & $\begin{array}{l}5.56 \\
(1.09)\end{array}$ & 2 & 0.69 & $\begin{array}{c}5.61 \\
(1.51)\end{array}$ \\
\hline & PBC & 2 & 0.41 & $\begin{array}{c}5.06 \\
(1.12)\end{array}$ & 2 & 0.33 & $\begin{array}{c}5.22 \\
(1.06)\end{array}$ & 2 & 0.32 & $\begin{array}{c}5.62 \\
(1.10)\end{array}$ \\
\hline & Intention strength & 3 & 0.87 & $\begin{array}{l}6.08 \\
(0.86)\end{array}$ & 3 & 0.93 & $\begin{array}{c}5.46 \\
(1.09)\end{array}$ & 3 & 0.97 & $\begin{array}{c}5.56 \\
(1.67)\end{array}$ \\
\hline & $\begin{array}{l}\text { Direct estimation of } \\
\text { intention }\end{array}$ & 1 & $\mathrm{n} / \mathrm{a}$ & $\begin{array}{c}9.00 \\
(1.82) \\
\end{array}$ & 1 & $\mathrm{n} / \mathrm{a}$ & $\begin{array}{l}7.68 \\
(2.11) \\
\end{array}$ & 1 & $\mathrm{n} / \mathrm{a}$ & $\begin{array}{c}7.36 \\
(3.44) \\
\end{array}$ \\
\hline \multirow[t]{2}{*}{ SCT } & Outcome expectancies & 3 & 0.72 & $\begin{array}{l}6.27 \\
(0.78)\end{array}$ & 3 & 0.95 & $\begin{array}{c}5.71 \\
(1.04)\end{array}$ & 3 & 0.70 & $\begin{array}{c}6.13 \\
(1.01)\end{array}$ \\
\hline & Self-efficacy & 10 & 0.92 & $\begin{array}{c}4.95 \\
(1.10) \\
\end{array}$ & 9 & 0.92 & $\begin{array}{r}4.63 \\
(1.13) \\
\end{array}$ & 4 & 0.90 & $\begin{array}{c}5.73 \\
(1.28) \\
\end{array}$ \\
\hline \multirow[t]{2}{*}{ LT } & $\begin{array}{l}\text { Anticipated } \\
\text { consequences }\end{array}$ & 2 & 0.40 & $\begin{array}{l}6.26 \\
(0.98)\end{array}$ & 2 & 0.52 & $\begin{array}{l}5.77 \\
(1.20)\end{array}$ & 2 & 0.37 & $\begin{array}{l}6.50 \\
(0.85)\end{array}$ \\
\hline & Evidence of habit & 2 & 0.69 & $\begin{array}{c}5.94 \\
(1.00) \\
\end{array}$ & 2 & 0.50 & $\begin{array}{c}5.41 \\
(1.17) \\
\end{array}$ & 2 & 0.81 & $\begin{array}{c}5.46 \\
(1.69) \\
\end{array}$ \\
\hline $\mathrm{n} / \mathrm{a}$ & $\begin{array}{l}\text { Self-reported habit } \\
\text { index }\end{array}$ & 12 & 0.93 & $\begin{array}{l}4.82 \\
(1.11)\end{array}$ & 12 & 0.94 & $\begin{array}{c}4.25 \\
(1.21)\end{array}$ & 12 & 0.96 & $\begin{array}{c}4.57 \\
(1.57)\end{array}$ \\
\hline $\mathrm{n} / \mathrm{a}$ & Past behaviour & 1 & $\mathrm{n} / \mathrm{a}$ & $\begin{array}{l}7.79 \\
(2.12)\end{array}$ & 1 & $\mathrm{n} / \mathrm{a}$ & $\begin{array}{l}6.39 \\
(2.11)\end{array}$ & 1 & $\mathrm{n} / \mathrm{a}$ & $\begin{array}{l}6.73 \\
(3.35)\end{array}$ \\
\hline \multirow[t]{3}{*}{ Plans } & Action planning & 3 & 0.92 & $\begin{array}{l}5.88 \\
(0.92)\end{array}$ & 3 & 0.94 & $\begin{array}{l}5.91 \\
(0.84)\end{array}$ & 4 & 0.94 & $\begin{array}{c}6.22 \\
(0.99)\end{array}$ \\
\hline & Coping planning & 10 & 0.96 & $\begin{array}{l}4.45 \\
(1.26)\end{array}$ & 9 & 0.95 & $\begin{array}{c}4.61 \\
(1.22)\end{array}$ & 4 & 0.97 & $\begin{array}{l}5.53 \\
(1.48)\end{array}$ \\
\hline & & \multicolumn{3}{|c|}{$\begin{array}{l}\text { Behaviour 4: Providing advice on } \\
\text { self-management }\end{array}$} & \multicolumn{3}{|c|}{$\begin{array}{c}\text { Behaviour 5: Prescribing } \\
\text { additional therapy for managing } \\
\text { glycaemic control }\end{array}$} & \multicolumn{3}{|c|}{$\begin{array}{l}\text { Behaviour 6: Providing general } \\
\text { education }\end{array}$} \\
\hline Model & Constructs & $\begin{array}{c}\mathrm{N} \\
\text { items }\end{array}$ & $\begin{array}{c}\text { Internal } \\
\text { consistency }\end{array}$ & $\begin{array}{l}\text { Mean } \\
\text { (SD) }\end{array}$ & $\begin{array}{c}\mathrm{N} \\
\text { items }\end{array}$ & $\begin{array}{c}\text { Internal } \\
\text { consistency }\end{array}$ & $\begin{array}{c}\text { Mean } \\
\text { (SD) }\end{array}$ & $\begin{array}{c}\mathrm{N} \\
\text { items }\end{array}$ & $\begin{array}{c}\text { Internal } \\
\text { consistency }\end{array}$ & $\begin{array}{c}\text { Mean } \\
\text { (SD) }\end{array}$ \\
\hline \multirow[t]{3}{*}{ TPB } & Attitude & 3 & 0.88 & $\begin{array}{l}6.29 \\
(0.82)\end{array}$ & 3 & 0.93 & $\begin{array}{l}6.00 \\
(0.79)\end{array}$ & 3 & 0.80 & $\begin{array}{l}6.37 \\
(0.75)\end{array}$ \\
\hline & Subjective norm & 2 & 0.56 & $\begin{array}{l}5.77 \\
(1.07)\end{array}$ & 2 & 0.47 & $\begin{array}{l}5.69 \\
(0.94)\end{array}$ & 2 & 0.57 & $\begin{array}{c}5.82 \\
(1.08)\end{array}$ \\
\hline & PBC & 2 & 0.50 & $\begin{array}{c}5.29 \\
(1.14)\end{array}$ & 2 & 0.36 & $\begin{array}{c}5.24 \\
(1.07)\end{array}$ & 2 & 0.49 & $\begin{array}{c}5.41 \\
(1.12)\end{array}$ \\
\hline TPB & Intention strength & 3 & 0.93 & $\begin{array}{c}5.73 \\
(1.17)\end{array}$ & 3 & 0.88 & $\begin{array}{l}5.57 \\
(0.94)\end{array}$ & 3 & 0.94 & $\begin{array}{c}5.92 \\
(1.03)\end{array}$ \\
\hline TPB & $\begin{array}{l}\text { Direct estimation of } \\
\text { intention }\end{array}$ & 1 & $\mathrm{n} / \mathrm{a}$ & $\begin{array}{l}8.16 \\
(2.35) \\
\end{array}$ & 1 & n/a & $\begin{array}{r}7.89 \\
(1.97) \\
\end{array}$ & 1 & $\mathrm{n} / \mathrm{a}$ & $\begin{array}{c}8.56 \\
(2.03) \\
\end{array}$ \\
\hline \multirow[t]{2}{*}{ SCT } & Outcome expectancies & 3 & 0.88 & $\begin{array}{c}6.29 \\
(0.82)\end{array}$ & 3 & 0.93 & $\begin{array}{l}6.00 \\
(0.79)\end{array}$ & 3 & 0.80 & $\begin{array}{c}6.37 \\
(0.75)\end{array}$ \\
\hline & Self-efficacy & 9 & 0.92 & $\begin{array}{l}5.38 \\
(1.05)\end{array}$ & 8 & 0.92 & $\begin{array}{c}5.04 \\
(1.10)\end{array}$ & 11 & 0.92 & $\begin{array}{c}4.79 \\
(1.09)\end{array}$ \\
\hline \multirow[t]{2}{*}{ LT } & $\begin{array}{l}\text { Anticipated } \\
\text { consequences }\end{array}$ & 2 & 0.42 & $\begin{array}{c}6.24 \\
(1.02)\end{array}$ & 2 & 0.57 & $\begin{array}{c}6.03 \\
(1.09)\end{array}$ & 2 & 0.54 & $\begin{array}{c}6.32 \\
(1.11)\end{array}$ \\
\hline & Evidence of habit & 2 & 0.81 & $\begin{array}{l}5.67 \\
(1.21) \\
\end{array}$ & 2 & 0.66 & $\begin{array}{l}5.61 \\
(1.01) \\
\end{array}$ & 2 & 0.81 & $\begin{array}{l}5.86 \\
(1.14) \\
\end{array}$ \\
\hline $\mathrm{n} / \mathrm{a}$ & $\begin{array}{l}\text { Self-reported habit } \\
\text { index }\end{array}$ & 12 & 0.96 & $\begin{array}{r}4.98 \\
(1.32) \\
\end{array}$ & 12 & 0.95 & $\begin{array}{c}4.42 \\
(1.25) \\
\end{array}$ & 12 & 0.96 & $\begin{array}{c}5.03 \\
(1.30) \\
\end{array}$ \\
\hline $\mathrm{n} / \mathrm{a}$ & Past behaviour & 1 & $\mathrm{n} / \mathrm{a}$ & $\begin{array}{l}7.72 \\
(2.42)\end{array}$ & 1 & $\mathrm{n} / \mathrm{a}$ & $\begin{array}{l}6.87 \\
(2.24)\end{array}$ & 1 & $\mathrm{n} / \mathrm{a}$ & $\begin{array}{c}7.93 \\
(2.36)\end{array}$ \\
\hline
\end{tabular}


Table 9 Internal consistency, means and standard deviations of scores for predictive clinical measures, by theoretical and conceptual model, for each of the six clinical behaviours (Continued)

\begin{tabular}{llccccccccc}
\hline Plans & Action planning & 3 & 0.96 & 5.44 & 3 & 0.97 & 5.62 & 3 & 0.97 & 5.58 \\
& & & $(1.16)$ & & & $(1.08)$ & $(1.17)$ \\
& & & & & 0.96 & 4.76 & 11 & 0.96 & 4.49 \\
& Coping planning & 9 & 0.96 & $(1.36)$ & & & $(1.31)$ & & $(1.26)$ \\
\hline
\end{tabular}

TPB Theory of Planned Behaviour, SCT Social Cognitive Theory, LT Learning Theory

All items scored 1 to 7 except for Direct estimation of intention and past behaviour which were scored 1 to 10 .

${ }^{1}$ Cronbach's alpha for measures with $>2$ items. Pearson correlations for measures with 2 items.

${ }^{2}$ Two sets of four self-efficacy items were used to assess self-efficacy to examine the circulation and sensation of feet separately. Internal consistency for the items measuring sensation was 0.91 , mean $=5.69, \mathrm{SD}=1.32$

shown in Table 10. Across the scenarios, there was no behaviour that all clinicians felt should be performed; for doctors, the scores ranged from $22 \%$ (scenario 3 ; prescribing additional therapy for the management of glycaemic control) to $89 \%$ (scenario 1; prescribing additional anti-hypertensive drugs), whilst for nurses the scores ranged from $18 \%$ (scenario 3; prescribing additional therapy for the management of glycaemic control) to $79 \%$ (scenario 1; giving advice about weight management).

\section{Clinician self-reported behaviour questionnaire and patient report of clinician behaviour}

The mean (SD) rates of performance of the six behaviours are shown in Table 10 along with the patient responses to the questions about the three receiving

Table 10 Measures of clinicians' behaviour

\begin{tabular}{|c|c|c|c|c|c|c|c|c|}
\hline \multirow[b]{2}{*}{$\begin{array}{l}\text { Measure of } \\
\text { behaviour }\end{array}$} & & & \multicolumn{6}{|c|}{ Behaviour } \\
\hline & & & $\begin{array}{l}\text { Provide advice about } \\
\text { weight management }\end{array}$ & $\begin{array}{l}\text { Prescribing for } \\
\text { the } \\
\text { management of } \\
\text { HbA1c }\end{array}$ & $\begin{array}{l}\text { Inspect } \\
\text { feet }\end{array}$ & $\begin{array}{c}\text { Provide } \\
\text { advice about } \\
\text { self- } \\
\text { management }\end{array}$ & $\begin{array}{c}\text { Prescribing } \\
\text { additional } \\
\text { antihypertensive } \\
\text { drugs }\end{array}$ & $\begin{array}{l}\text { Provide } \\
\text { general } \\
\text { patient } \\
\text { education }\end{array}$ \\
\hline \multirow{8}{*}{$\begin{array}{l}\text { Behaviour } \\
\text { simulation } \\
\text { scenarios } \% \text { (n) } \\
\text { would do or } \\
\text { would do if time }\end{array}$} & GPS & Scenario 1 & $77 \%$ (279) & $36 \%(131)$ & $63 \%(229)$ & $54 \%(195)$ & $89 \%$ (320) & $61 \%(219)$ \\
\hline & Nurses & & $79 \%(147)$ & $22 \%(40)$ & $70 \%(130)$ & $67 \%(125)$ & $76 \%(141)$ & $66 \%(123)$ \\
\hline & GPS & Scenario 2 & $77 \%(276)$ & $85 \%(305)$ & $58 \%(210)$ & $53 \%(190)$ & $46 \%(167)$ & $63 \%(228)$ \\
\hline & Nurses & & $75 \%(140)$ & $68 \%(127)$ & $68 \%(126)$ & $66 \%(122)$ & $51 \%(95)$ & $70 \%(130)$ \\
\hline & GPS & Scenario 3 & $68 \%(246)$ & $22 \%(78)$ & $52 \%(188)$ & $41 \%(149)$ & $81 \%(294)$ & $53 \%(191)$ \\
\hline & Nurses & & $70 \%(130)$ & $18 \%(34)$ & $67 \%(124)$ & $60 \%(112)$ & $65 \%(121)$ & $62 \%(115)$ \\
\hline & GPs & Scenario 4 & $68 \%(246)$ & $84 \%(302)$ & $51 \%(183)$ & $45 \%(163)$ & $72 \%(260)$ & $61 \%(221)$ \\
\hline & Nurses & & $71 \%(132)$ & $65 \%(120)$ & $61 \%(113)$ & $58 \%(108)$ & $62 \%(116)$ & $68 \%(127)$ \\
\hline \multirow{2}{*}{$\begin{array}{l}\text { 12-month self } \\
\text { report \#\# }\end{array}$} & GPS & Mean (SD) & 7.56 (2.20) & $6.93(2.50)$ & $5.40(3.47)$ & $7.24(2.45)$ & $6.68(2.38)$ & $7.40(2.44)$ \\
\hline & Nurses & Mean (SD) & $9.03(1.91)$ & 7.96 (2.09) & $9.16(1.89)$ & $8.90(2.03)$ & $5.91(3.15)$ & $8.86(2.20)$ \\
\hline \multicolumn{2}{|l|}{ Patient report } & $\begin{array}{l}\%(n) \\
\text { (single } \\
\text { item) }\end{array}$ & $51 \%(1716)^{1}$ & $\mathrm{n} / \mathrm{a}$ & $91 \%(3078)^{2}$ & $68 \%(2292)^{3}$ & $n / a$ & $\begin{array}{c}73 \% \\
(2443)^{4}\end{array}$ \\
\hline \multicolumn{2}{|l|}{ Patient report } & $\begin{array}{l}\text { N items } \\
\text { Mean (SD) } \\
\text { (composite) }\end{array}$ & $\begin{array}{c}8 \\
2.50(2.25)\end{array}$ & $\mathrm{n} / \mathrm{a}$ & $\mathrm{n} / \mathrm{a}$ & $\begin{array}{c}3 \\
1.51(0.99)\end{array}$ & $\mathrm{n} / \mathrm{a}$ & $\begin{array}{l}18 \\
7.44 \\
(5.16)\end{array}$ \\
\hline \multicolumn{3}{|l|}{$\begin{array}{l}\text { Practice } \\
\text { computer data }\end{array}$} & $\begin{array}{c}\text { 81.3\% (23864/29362) } \\
\text { patients with record } \\
\text { weight or BMI Mean } \\
\text { BMI } 30.74(95 \% \text { Cl: } 30.67 \text {, } \\
38.83)\end{array}$ & $\begin{array}{c}58.9 \%(624 / 1059) \\
\text { of eligible } \\
\text { patients } \\
\text { prescribed an } \\
\text { additional therapy }\end{array}$ & $\begin{array}{l}77.1 \% \\
(22640 / \\
\text { 29362) with } \\
\text { record of } \\
\text { foot exam }\end{array}$ & n/a & $\begin{array}{c}39.5 \%(1595 / 4038) \\
\text { patients } \\
\text { prescribed an } \\
\text { additional therapy }\end{array}$ & $\mathrm{n} / \mathrm{a}$ \\
\hline \multicolumn{9}{|c|}{ \# For behaviour simulation, the denominator for GPs was 361 and for nurses, 186.} \\
\hline \multirow{2}{*}{\multicolumn{9}{|c|}{$\begin{array}{l}{ }^{1} \text { Responded 'Yes' to the question 'Thinking about the last } 12 \text { months, when you received care for your diabetes from a doctor or nurse were you given advice } \\
\text { about how to manage your weight?' } \\
{ }^{2} \text { Responded 'Yes' to the question 'In the last } 12 \text { months have you had your bare feet examined? }\end{array}$}} \\
\hline & & & & & & & & \\
\hline \multicolumn{9}{|c|}{${ }^{3}$ Same stem as 1; Responded 'Yes' to the question 'were you given advice about how YOU should manage YOUR diabetes?' } \\
\hline \multicolumn{9}{|c|}{${ }^{4}$ Same stem as 1; Responded 'Yes' to the question 'were you provided with general information about diabetes?' } \\
\hline
\end{tabular}


advice behaviours and foot examination. Within the self-report questions, for both groups of clinicians, although reported rates of performing the behaviours were high, with two-thirds of rates being above seven out of ten, there was variation within the rates with standard deviations generally being just over two. Nurses reported performing the three 'giving advice' behaviours more often than doctors did, reporting performing the behaviour for almost 9 out of 10 patients. For foot examination, there was the widest difference between doctors and nurses, potentially reflecting different agreed roles and different patient populations seen.

The single-item patient report data are directly comparable to the clinician report data and, for foot examination, the patients' reports matched the nurses selfreport almost exactly. For the other three advising behaviours, the patient-reported rates of receiving advice are consistently lower than the clinicianreported rates of giving it. For advice about self-management and providing advice about general education (converting the clinician $\mathrm{n} / 10$ scores into percentages) the gap is $21 \%$ and $14 \%$, respectively. For advice about weight management, the gap is $52 \%$ with clinicians reporting that they gave advice about twice as often as patients reported receiving it.

When testing the composite items, the principal components analysis (PCA) on items within each behaviour suggested that each involved more than one component. For providing weight management advice and providing general education, these did not outweigh the clinical face validity of the initial scales nor did removing items improve the internal consistency. For providing self-management advice, PCA results informed the decision to remove three items. For the resulting composite measures, there were eight items for providing weight management advice (Cronbach's alpha 0.80), three items for providing self-management advice (Cronbach's alpha 0.66), and 18 items for providing general education (Cronbach's alpha 0.91). Details of the items and the analysis are in Additional File 6.

The mean (SD) scores for the composite items are shown in Table 10. For providing weight management advice, $51 \%$ of patients endorsed the single item but the mean number of items endorsed was $2.5 / 8$, although $71 \%$ responded 'yes' to at least one item. Similarly, for providing self-management advice, $67.5 \%$ of patients endorsed the single item, the mean score on the composite measure was $1.5 / 3$ and $83.4 \%$ responded 'yes' to at least one item; for providing general education, $72.3 \%$ endorsed the single item, the mean score on the composite measure was 7.4/18 and 93\% responded 'yes' to at least one item.

\section{Clinician behaviour based on data extracted from practice computer systems Running the query}

Of the 99 included practices, one refused to run the data extraction query because of previous problems when running computer data extraction queries. For seven practices operating one computer system the query did not work, and four practices did not run the query despite repeated reminders. Thus 87 of the 99 practices ran the electronic query. For four of the practices, there was no usable drug data; the issuing of prescriptions was recorded but not the drug name or dose. A fifth practice had many missing data items for the second year-no patients in that practice were found as being eligible for the addition of an extra therapy to control their HbA1c and there were no recorded feet inspections in year two (although there were many recorded in year one). A sixth practice had no eligible patients for the glycaemic control behaviour. Therefore the analyses of behaviour two (prescribing additional antihypertensive drugs) and behaviour five (prescribing additional therapy for managing glycaemic control) are based on 83 and 81 practices, respectively, with 86 practices being analysed for behaviour three (examining feet).

\section{Computer data and the study behaviours}

The rates of the study behaviours are in Table 10. The data extracted from the practice computers are usually of the form of process (recording that a behaviour was done such as issuing a prescription) or intermediate patient outcome measures (such as recorded BP). The links between this data and the study behaviours are more or less direct. For behaviour one (providing advice on weight management), data for weight/height/body mass index (BMI) was available from all practices and reflects the physiological endpoint of the behaviour we asked about. However, assuming such advice is given, there are a number of clinician (how well was it given) and patient (was it heard, accepted, acted upon) factors that intervene before any effect of performing the behaviour plays out through a change in a measure such as BMI. Unfortunately, the available computer codes for offering advice about weight though present were infrequently used and hence cannot be used as an outcome measure in this project. Behaviour two (prescribing additional antihypertensive drugs) and behaviour five (prescribing additional therapy for managing glycaemic control) relate to drug prescription in relation to physical examination or laboratory test results. Values for BP and $\mathrm{HbA1c}$ were universally available, and drug data that was available from 81 practices. The analysis is currently computing the eligible patient populations (BP > $145 / 85$; HbA1c > 8.0) and whether or not relevant 
treatment was increased or added at relevant consultations. This is entailing a considerable amount of coding of frequency of dose data (usually entered as text rather than coded data) and coding of maximum doses of drugs to allow the identification of a population of patients who most closely match the behaviour. Although time consuming, this will provide a much more precise measure of a prescribing behaviour than we have been able to achieve in previous studies where we relied on routine data [5]. Data on the rates of performing behaviour three (examining feet) was available from 86 practices. For behaviours four and six, we found low rates of relevant computer codes both within and across practices. For behaviour four (providing advice on self management), we have computer code data for 68 practices (and from only 63 of these in the year following completion of the questionnaires); in addition, we have coded data on the provision of diabetes self-monitoring equipment (the use of which can form part of self-management) recorded from 47 practices. Patient education codes (behaviour six) were recorded in only 33 practices (and in 19 in the year following completion of the baseline questionnaires). Therefore, for these two behaviours we will be using the patients report data as our main measure of the behaviour.

\section{Quality and Outcomes Framework data}

The QOF data are shown in Table 11. The QOF scores give a routinely available measure of clinical and organisational performance, though the rates of achievement against the organisational indicators are almost maximal, suggesting that these indicators will not usefully discriminate. QOF is also limited in terms of how the

Table 11 QOF scores on each of the DM indicators, by practice $(n=99)$ for the 12 month period May 2008 to April 2009

\begin{tabular}{|c|c|}
\hline QOF Indicator & $\%$ achievement \\
\hline Diabetes Mellitus & $\begin{array}{l}\text { Mean (SD); } \min , \\
\quad \max \end{array}$ \\
\hline \multicolumn{2}{|l|}{ The percentage of patients with diabetes ... in the previous 15 months } \\
\hline whose notes record $\mathrm{BMI}$ & $96(3) ; 82,100$ \\
\hline who have a record of $\mathrm{HbA} 1 \mathrm{c}$ or equivalent & $98(2) ; 85,100$ \\
\hline in whom the last $\mathrm{HbA1c}$ is 7.5 or less (or equivalent) & $68(9) ; 54,95$ \\
\hline in whom the last $\mathrm{HbA} 1 \mathrm{c}$ is 10 or less (or equivalent) & $93(4) ; 76,100$ \\
\hline who have a record of retinal screening & $93(4) ; 77,100$ \\
\hline with a record of the presence/absence of peripheral pulses & $92(6) ; 49,100$ \\
\hline with a record of neuropathy testing & $92(6) ; 49,99$ \\
\hline who have a record of their blood pressure & $99(1) ; 96,100$ \\
\hline in whom the last blood pressure is $145 / 85$ or less* & $80(7) ; 59,97$ \\
\hline who have a record of micro-albuminuria testing & $90(6) ; 64,100$ \\
\hline who have a record of eGFR ${ }^{* *}$ or serum creatinine testing & $98(2) ; 85,100$ \\
\hline with a diagnosis of proteinuria or micro-albuminuria who are treated with ACE inhibitors (or A2 antagonists)* & $93(6) ; 75,100$ \\
\hline who have a record of total cholesterol & $97(2) ; 86,100$ \\
\hline whose last measured total cholesterol is $5 \mathrm{mmol} / \mathrm{l}$ or less & $84(6) ; 66,98$ \\
\hline who have had influenza immunisation in the preceding 1 September to 31 March* $^{*}$ & $91(6) ; 57,100$ \\
\hline $\begin{array}{c}\text { The practice can produce a register of all patients aged } 17 \text { years and over with diabetes mellitus, which specifies whether the } \\
\text { patient has Type } 1 \text { or Type } 2 \text { diabetes*** }\end{array}$ & $6(0) ; 6,6$ \\
\hline \multicolumn{2}{|l|}{ Practice organisation } \\
\hline Total score for records and information & $84.7(5.4) ; 38.3,87$ \\
\hline Total score for information for patients & $2.9(0.4) ; 0.0,3.0$ \\
\hline Total score for education and training & $27.2(4.0) ; 0.0,28$ \\
\hline Total score for practice management & $13.2(1.9) ; 0.0,13.5$ \\
\hline Total score for medicines management & $35.0(5.3) ; 0.0,36.0$ \\
\hline
\end{tabular}

\footnotetext{
* not dated to previous 15 months

** estimated glomerular filtration rate

*** numerator and denominator not available; QOF score reported
} 
indicators relate to the clinical behaviours of interest within this project. Neither the behaviour 'giving advice about self-management' nor 'providing general education' have any useful match within the QOF data. For 'giving advice about weight management' the only indicator related to weight is 'patients' notes recording BMI' and, although this might reflect on the organisation of a practice, with mean achievement levels of $96 \%$ and a standard deviation of three, like the other organisational indicators, it too is unlikely to have sufficient variation to be discriminating. There is a good match for 'foot examination' and the mean achievement levels of $92 \%$ match the clinician and patient report well. For the other two behaviours 'prescribing additional anti-hypertensive drugs' and 'prescribing additional therapy for the management of glycaemic control,' there are indicators that could reflect the active performance of the two behaviours. In practices where clinicians are actively trying to tightly control both $\mathrm{BP}$ and glycaemic control, it would be reasonable to expect higher rates of patients with lower BP and HbA1c-and there is one QOF indicator for each of these with rates of performance of $80 \%$ and $68 \%$ respectively.

\section{Discussion}

We have assembled an unparalleled data set from clinicians reporting on their cognitions in relation to the performance of six clinical behaviours involved in the management of people with one chronic disease (diabetes mellitus), using a range of organisational and individual level measures as well as information on the structure of the practice teams and across a large number of UK primary care practices.

In the context of generally falling response rates to postal questionnaire surveys of clinicians [49], we have previously had to deal with low response rates for theory-based questionnaires surveys [4-6,50]. As a consequence, we have had to contend with the fact that the data from such studies may not be representative. In this study, individual response rates varied by the clinical behaviour and whether it was the responsibility of the respondent to perform that behaviour (e.g., nurses who didn't prescribe didn't answer the two prescribing behaviours questions); nonetheless, we achieved individual response rates that varied within practices from 71 to $96 \%$, figures far higher than usually achieved [49]. We assume that this is in part due to working with motivated practices (though this may compromise representativeness in a different way) and using a powerful behaviour change technique of offering reward (payment) based on satisfactory completion rates by practices rather than simply compensation for each individual's time involved in completing the questionnaires.
More importantly, because diabetes is a condition cared for by the integrated behaviours of multiple team members, we were particularly interested in achieving high levels of responses from all clinicians (physicians and nurses) within a practice. We achieved 100\% response rates from clinicians in 40 practices, and achieved responses from over $80 \%$ of clinicians in 58 practices; for the questions about the six clinical behaviours, these figures rose to 60 and 76, respectively. However, despite working with research active practices, stressing the requirement for high response rates and recompensing them for their completion, for between 1 and 13 practices (depending on the section of the questionnaire) we received responses from less than $50 \%$ of eligible respondents.

Whilst the organisational measures were standard questionnaires (and achieved expected levels of internal consistency), our operationalisation of the individual cognition measures was good with measures of internal consistency all well within accepted ranges and good content coverage of the constructs. Many of the individual cognition scores are high, suggesting that respondents are already positively inclined towards performing the behaviours. These two groups of measures will together form a large part of our explanatory variables in explaining variation in rates of performing the behaviours. A standard analysis would calculate the variance in behaviour explained by each measure but, under circumstances such as these (where values are very positive), it is possible that contextual and environmental factors are important in whether or not the behaviours are successfully performed. Given the range of such factors that we have measured, we will be able to perform a more comprehensive analysis to generate hypotheses about where it might be best to intervene to improve performance.

We have successfully collected a number of different proxy measures of behaviour. These are a mix of individual level measures (self report, scenario simulation scores) and practice level measures (patient report, clinical data from practice computers, and QOF data). They also represent a range of measures of performing the behaviour (self-report) through to measures of the physiological consequences of the behaviour having been performed (measures from the practice computer such as BMI, $\mathrm{BP}$, and $\mathrm{HbA1c}$ ).

We extracted a considerable dataset relevant to the behaviours from the computers of the participating practices. Having defined six specific behaviours important to the management of patients with type 2 diabetes, it is salutary to reflect that only one (foot examination) was readily available within the computer records. For two of the behaviours (prescribing for BP control and glycaemic control), we will be able to compute an 
accurate measure (after considerable data processing), and for one other the computer record contained a physiological measure reflecting the performance of the behaviour across several links and interactions with other factors in a causal chain (BMI for advising about weight management). For the other two (advising behaviours), the computer record contained inconsistently recorded, and ultimately unusable, data.

These was no single, ideal, measure of behaviour, and any study such as this will have to balance the strengths and weaknesses of different measures of behaviour. It is not difficult to produce a list of potential biases-clinician self-report will be susceptible to a desirability reporting bias, simulated behaviour scores from the scenarios will be complicated to interpret and score, patient report will be susceptible to (at least) non-response, and recall biases and computer records will be susceptible to recording bias. However, for a study conducted on this scale, there is no ready alternative to the behaviour measures that we have collected, and whilst we will need to be sensitive to the potential shortcomings of the data in our analyses, we do not believe it is possible to produce better measures. While each of these measures on its own could present constraints as a true measure of the target behaviours, having all five measures will allow cross-validation.

Making simultaneous measurement across six behaviours allows a degree of comparison not previously reported in the implementation literature. It is clear from the data presented here that cognitions (all measured at the same point in time) vary across behaviours. Using direct estimation of intention as an example, this varies from 7.4 (out of a possible 10) for examining feet to 9.0 for providing weight management advice for 10 patients. The availability of such variation within and across behaviours should strengthen our ability to explain behaviour.

Given that the data held in practice computers represents the actions of different members of the practice team, the measures of self-report behaviour and simulated behaviour represent our only individual level measures of behaviour. In order to analyse the practice level data (from patient report, the practice computer systems, and QOF), we are going to have to deal with how best to aggregate our individual-level explanatory measures up to that of the team or organisation. Many previous measures have used the arithmetic mean, but it is by no means clear that this is the best metric for aggregation [51]. Approaches such as weighting systems using the scores of those whose role it is to perform the relevant behaviour may represent a better way forward.

The dataset that we have assembled represents one of the most comprehensive of its type, and the research team is very keen to maximise the use of it. To this end, we would welcome approaches to collaborate on the analysis of this data from other researchers and, once we have completed our main analyses, would be willing to explore making suitably anonymised data available to external groups for collaborative analyses.

\section{Conclusions}

This paper is the first of a series of papers. It reports in detail the instrument development and data collected. Analyses of this large data set will, we hope, lead to the development of a series of strategies aimed at promoting the improvement of care for patients with diabetes as well as a series of rich insights into organisational and individual factors influencing clinician behaviour.

\section{Additional material}

\section{Additional file 1: Telephone interview schedule.pdf. Pdf file Organisational structure telephone interview schedule.}

Additional file 2: Baseline Postal Questionnaire.pdf. Pdf file. Baseline Postal Questionnaire incorporating organisational and clinical questionnaires and behaviour simulation measures.

Additional file 3: 12 month clinician self report behaviour questionnaire.pdf. Pdf file. 12 month clinician self report behaviour questionnaire.

Additional file 4: Computer Read Codes.pdf. Pdf file. List of primary care practice computer data extraction items.

Additional file 5: Patient Questionnaire.pdf. Pdf File. Patient questionnaire items.

Additional file 6: Deriving composite measures from the patients survey items.pdf. Pdf file. Items and analysis for composite measures from the patient survey.

\section{Acknowledgements and funding}

The study is funded by Diabetes UK http://www.diabetes.org.uk/. We are grateful to Rachel Wright for designing and running the computer data extraction query. Jill Francis is funded by the Chief Scientist Office of the Scottish Government Health Directorates. Jeremy Grimshaw holds a Canada Research Chair in Health Knowledge Transfer and Uptake.

\section{Author details}

${ }^{1}$ Institute of Health and Society, Newcastle University, Baddiley-Clark Building, Richardson Road, Newcastle upon Tyne, NE2 4AX, UK. ${ }^{2}$ Health Services Research Unit, University of Aberdeen, Health Sciences Building, Foresterhill, Aberdeen, AB25 2ZD, UK. ${ }^{3}$ College of Life Sciences and Medicine, University of Aberdeen, Health Sciences Building, Foresterhill, Aberdeen, AB25 2ZD, UK. ${ }^{4}$ Diabetes Centre, Newcastle Primary Care Trust, Newcastle upon Tyne, UK. ${ }^{5}$ Clinical Epidemiology Program, Ottawa Health Research Institute, Ottawa and Department of Medicine, University of Ottawa, Canada, 1053 Carling Avenue, Administration Building, Room 2-017, Ottawa ON, K1Y 4E9, Canada. ${ }^{6}$ National Institute for Health and Welfare, Health Services Research Unit, PO Box 30, 00271 Helsinki, Finland.

\section{Authors' contributions}

The study was conceived by MPE, JJF, MJ, NS, JMG, ME, GH, and MH. The study was run by $\mathrm{SH}$ and MPE with data handling and analyses by $\mathrm{SH}, \mathrm{ES}$, JP, and NS, and ongoing advice on operationalisation of theoretical constructs by ME, MJ, and JJF. Writing of the paper was led by MPE and SH with all authors commenting on drafts and approving the final version. 


\section{Competing interests}

Martin Eccles is Co-Editor in Chief of Implementation Science and Jeremy Grimshaw is a member of the Editorial Board of Implementation Science; all decisions on this paper were made by another editor.

Received: 1 April 2011 Accepted: 9 June 2011 Published: 9 June 2011

\section{References}

1. Davies $P$, Walker AE, Grimshaw JM: A systematic review of the use of theory in the design of guideline dissemination and implementation strategies and interpretation of the results of rigorous evaluations. Implementation Science 2010, 5(14).

2. Godin G, Belanger-Gravel A, Eccles M, Grimshaw J: Healthcare professionals' intentions and behaviours: A systematic review of studies based on social cognitive theories. Implementation Science 2008, 3(36).

3. Chabot G, Godin G, Gagnon MP: Determinants of the intention of elementary school nurses to adopt a redefined role in health promotion at school. Implementation Science 2010, 5(93).

4. Bonetti D, Pitts NB, Eccles M, Grimshaw J, Steen N, Glidewell L, Thomas R, Maclennan G, Clarkson JE, Walker A, et al: Applying psychological theory to evidence-based clinical practice: identifying factors predictive of taking intra-oral radiographs. Soc Sci Med 2006, 63:1889-1899.

5. Eccles MP, Grimshaw J, Johnston M, Steen IN, Pitts NB, Thomas R: Applying psychological theories to evidence-based clinical practice: Identifying factors predictive of managing upper respiratory tract infections without antibiotics. Implementation Science 2007, 2:26.

6. Bonetti D, Johnston M, Clarkson JE, Grimshaw J, Pitts NB, P EM, Steen IN, Thomas R, MacLennan G, Glidewell L, et al: Applying psychological theories to evidence-based clinical practice: identifying factors predictive of placing preventive fissure sealants. Implementation Science 2010, 5(25)

7. Bonetti D, Young L, Black I, Cassie H, Ramsay CR, Clarkson J: Can't do it, won't do it! Developing a theoretically framed intervention to encourage better decontamination practice in Scottish dental practices. Implementation Science 2009, 4(31).

8. Francis JJ, Eccles MP, Johnston M, Whitty P, Grimshaw JM, Kaner EFS, Smith L, Walker A: Explaining the effects of an intervention designed to promote evidence-based diabetes care: a theory-based process evaluation of a pragmatic cluster randomised controlled trial. Implementation Science 2008, 3(50).

9. Ramsay CR, Thomas RE, Croal BL, Grimshaw JM, Eccles MP: Using the theory of planned behaviour as a process evaluation tool in randomised trials of knowledge translation strategies: a case study from UK primary care. Implementation Science 2010, 5(71).

10. Michie S, Johnston M, Abraham C, Lawton R, Parker D, Walker A: 'Psychological Theory' Group. Making psychological theory useful for implementing evidence based practice: a consensus approach. Quality \& Safety in Health Care 2005, 14(1):26-33.

11. Damschroder LJ, Aron DC, Keith RE, Kirsh SR, Alexander JA, Lowery JC: Fostering implementation of health services research findings into practice: a consolidated framework for advancing implementation science. Implementation Science 2009, 4(50).

12. Walker A, Grimshaw JM, Johnston M, Pitts N, Steen N, Eccles MP: PRocess modelling in ImpleMEntation research:selecting a theoretical basis for interventions to change clinical practice. BMC Health Services Research 2003, 3:22.

13. Bonetti D, P EM, Johnston M, Steen IN, Grimshaw J, Baker R: Guiding the design and selection of interventions to influence the implementation of evidence-based practice: an experimental simulation of a complex intervention trial. Soc Sci Med 2005, 60:2135-2147.

14. Francis JJ, Tinmouth A, Stanworth SJ, Grimshaw J, Johnston M, Hyde C, Stockton C, Brehaut JC, Fergusson D, P EM: Using theories of behaviour to understand transfusion prescribing in three clinical contexts in two countries: development work for an implementation trial. Implementation Science 2009, 4(70)

15. Francis JJ, Stockton C, P EM, Johnston M, Cuthbertson BH, Grimshaw J, Hyde C, Tinmouth A, Stanworth SJ: Evidence-based selection of theories for designing behaviour change interventions: using methods based on theoretical construct domains to understand clinicians' blood transfusion behaviour. British Journal of Health Psychology 2009, 14:625-646.
16. Bonetti D, Johnston M, Clarkson J, Turner S: Applying multiple models to predict clinicians' behavioural intention and objective behaviour when managing children's teeth. Psychol Health 2009, 24(7):843-860.

17. Seddon ME, Marshall MN, Campbell SM, Roland MO: Systematic review of studies of quality of clinical care in general practice in the UK, Australia and New Zealand. QHC 2001, 10(3):152-158.

18. Eccles MP, Hawthorne G, Johnston M, Hunter M, Steen N, Francis J, Hrisos S, Elovainio M, Grimshaw JM: Improving the delivery of care for patients with diabetes through understanding optimised team work and organisation in primary care. Implementation Science 2009, 4(22).

19. National Collaborating Centre for Chronic Conditions: Type 2 diabetes: national clinical guideline for management in primary and secondary care (update). London: Royal College of Physicians; 2008.

20. Fishbein M: Attitude and the prediction of behavior. In Readings in attiude theory and measurement. Edited by: Fishbein M. New York: Wiley; 1967:477-492.

21. Davies HTO, Nutley SM, Mannion R: Organisational culture and quality of health care. QHC 2000, 9:111-119.

22. Schuster M, McGlynn E, Brook RH: How good is the quality of health care in the United States? Milbank Q 1998, 76(517):563.

23. Homans GC: Social behaviour as exchange. American Journal of Sociology 1958, 63:597-606.

24. Blau P: Exchange and power in social life New York: Wiley; 1964

25. Elovainio M, Kivimaki M, Vahtera J: Organisational justice: evidence of a new psychosocial predictor of health. Journal of Public Health 2002, 92:1058.

26. Karasek: Job content questionnaire and user's guide. Volume Revision 1.1.1985 1985.

27. Kivimaki M, Elovainio M: A short version of the team climate inventory: development and psychometric properties. Journal of Occupational and Organizational Psychology 1999, 72:241-246.

28. Moorman RH: Relationship between organizational justice and organizational citizenship behaviors: do fairness perception influence employee citizenship? J Appl Psychol 1991, 76:845-855.

29. Goldberg DP, Hillier VF: A scaled version of the General Health Questionnaire. Psychol Med 1979, 9:139-145.

30. Ajzen I: The theory of planned behaviour. Organizational Behaviour and Human Decision Processes 1991, 50:179-211.

31. Bandura A: Self-efficacy: towards a unifying theory of behaviour change. Psychological Review 1977, 84:191-215.

32. Bandura A: Self-efficacy: the exercise of control New York: Freeman; 1997.

33. Blackman D: Operant conditioning: an experimental analysis of behaviour London: Methuen; 1974.

34. [http://www.bfskinner.org/BFSkinner/Home.html].

35. Verplanken B, Orbell S: Reflections on past behavior: a self-report index of habit strength. Journal of Applied Social Psychology 2003, 33:1313-1330.

36. Sniehotta FF, Scholz U, Schwarzer R: Bridging the intention-behaviour gap: planning, self-efficacy, and action control in the adoption and maintenance of physical exercise. Psychology \& Health 2005, 20:143-160,

37. Sniehotta FF, Schwarzer R, Scholz U, Schuz B: Action planning and coping planning for long-term lifestyle change: theory and assessment. Eur J Soc Psychol 2005, 35:565-576.

38. Hrisos S, P EM, M J, Francis J, S KEF, Steen IN, Grimshaw J: Developing the content of two behavioural interventions: Using theory-based interventions to promote GP management of upper respiratory tract infection without prescribing antibiotics \#1. BMC Health Services Research 2008, 8:11.

39. Hrisos S, Eccles MP, Johnston M, Francis J, Kaner E, Steen IN, Grimshaw J: An intervention modelling experiment to change GPs' intentions to implement evidence-based practice: Using theory-based interventions to promote GP management of upper respiratory tract infection without prescribing antibiotics \#2. BMC Health Services Research 2008, 8:10.

40. Eccles MP, Johnston M, Hrisos S, Francis J, Grimshaw J, Steen IN, Kaner EF: Translating clinicians' beliefs into implementation interventions (TRACII): a protocol for an intervention modelling experiment to change clinicians' intentions to implement evidence-based practice. Implementation Science 2007, 2(27).

41. Collins D: Pretesting survey instruments: an overview of cognitive methods. Qual Life Res 2003, 12:229-238.

42. The Healthcare Commission: The views of people with diabetes: key findings from the 2006 survey 2007. 
43. Roland M: Linking physicians' pay to the quality of care. $N$ Engl J Med 2004, 351:1448.

44. Campbell SM, Reeves D, Kontopantelis E, Sibbald B, Roland M: Effects of pay-for-performance on the quality of primary care in England. $N$ Engl J Med 2009, 361:368-378.

45. The Information Centre: General and personal medical services: England, 1997-2007. Leeds: The Information Centre; 2008.

46. Goh T, Eccles MP: Team climate and quality of care in primary health care: a review of studies using the Team Climate Inventory in the United Kingdom. BMC Research Notes 2009, 2(222).

47. Goh T, Eccles MP, Steen IN: Factors predicting team climate, and its relationship with quality of care in general practice. BMC Health Services Research 2009, 9(138).

48. Karasek R, Brisson C, Kawakami N, Houtman I, Bongers P, Amick B: The job content questionnaire (JCQ): an instrument for internationally comparative assessments of psychosocial job characteristics. Journal of Occupational Health Psychology 1998, 3(4):322-355.

49. Cook JVF, Dickinson H, Eccles MP: Response rates in postal surveys of healthcare professionals between 1996 and 2005: an observational study. BMC Health Services Research 2009, 9(160).

50. Hrisos S, Eccles MP, Francis JJ, Bosch M, Dijkstra R, Johnston M, Grol R, Kaner EFS, Steen IN: Using psychological theory to understand the clinical management of type 2 diabetes in primary care: a comparison across two European countries. BMC Health Services Research 2009, 9(140).

51. Eccles MP, Hrisos S, Francis JJ, Steen IN, Bosch M, Johnston M: Can the collective intentions of individual professionals within healthcare teams predict the team's performance: developing methods and theory. Implementation Science 2009, 4(24).

doi:10.1186/1748-5908-6-61

Cite this article as: Eccles et al: Instrument development, data collection, and characteristics of practices, staff, and measures in the Improving Quality of Care in Diabetes (iQuaD) Study. Implementation Science 2011 6:61.

\section{Submit your next manuscript to BioMed Central and take full advantage of:}

- Convenient online submission

- Thorough peer review

- No space constraints or color figure charges

- Immediate publication on acceptance

- Inclusion in PubMed, CAS, Scopus and Google Scholar

- Research which is freely available for redistribution

Submit your manuscript at www.biomedcentral.com/submit
Ciomed Central 